\title{
Proteolysis and biogenic amine buildup in high-pressure treated ovine milk blue-veined cheese
}

\author{
J. Calzada, A. Del Olmo, A. Picon, P. Gaya, and M. Nuñez ${ }^{1}$ \\ Departamento de Tecnología de Alimentos, Instituto Nacional de Investigación y Tecnología Agraria y Alimentaria, 28040 Madrid, Spain
}

\begin{abstract}
Penicillium roqueforti plays an important role in the ripening of blue-veined cheeses, mostly due to lactic acid consumption and to its extracellular enzymes. The strong activity of $P$. roqueforti proteinases may bring about cheese over-ripening. Also, free amino acids at high concentrations serve as substrates for biogenic amine formation. Both facts result in shorter product shelf-life. To prevent over-ripening and buildup of biogenic amines, blue-veined cheeses made from pasteurized ovine milk were high-pressure treated at 400 or $600 \mathrm{MPa}$ after 3, 6, or 9 wk of ripening. Primary and secondary proteolysis, biogenic amines, and sensory characteristics of pressurized and control cheeses were monitored for a 90-d ripening period, followed by a $270-$ $\mathrm{d}$ refrigerated storage period. On d 90, treatments at $400 \mathrm{MPa}$ had lowered counts of lactic acid bacteria and $P$. roquefort $i$ by less than $2 \log$ units, whereas treatments at $600 \mathrm{MPa}$ had reduced lactic acid bacteria counts by more than $4 \log$ units and $P$. roqueforti counts by more than $6 \log$ units. No residual $\alpha$-casein $(\mathrm{CN})$ or $\kappa$-CN were detected in control cheese on d 90. Concentrations of $\beta-\mathrm{CN}$, para- $\kappa-\mathrm{CN}$, and $\gamma-\mathrm{CN}$ were generally higher in $600 \mathrm{MPa}$ cheeses than in the rest. From d 90 onwards, hydrophilic peptides were at similar levels in pressurized and control cheeses, but hydrophobic peptides and the hydrophobic-to-hydrophilic peptide ratio were at higher levels in pressurized cheeses than in control cheese. Aminopeptidase activity, overall proteolysis, and free amino acid contents were generally higher in control cheese than in pressurized cheeses, particularly if treated at $600 \mathrm{MPa}$. Tyramine concentration was lower in pressurized cheeses, but tryptamine, phenylethylamine, and putrescine contents were higher in some of the pressurized cheeses than in control cheese. Differences in sensory characteristics between pressurized and control cheeses were generally negligible, with the only exception of treatment at high pressure level (600
\end{abstract}

Received November 23, 2012.

Accepted April 10, 2013.

${ }^{1}$ Corresponding author: nunez@inia.es
$\mathrm{MPa})$ at an early ripening stage (3 wk), which affected biochemical changes and sensory characteristics.

Key words: blue cheese, high pressure, biogenic amine, proteolysis

\section{INTRODUCTION}

Indigenous milk enzymes, coagulant enzymes, lactic acid bacteria (LAB) from starter cultures, and other added or contaminating microorganisms and their enzymes degrade milk proteins to peptides and free AA during cheese manufacture and ripening (Visser, 1993). Peptides contribute to cheese flavor, in most cases positively, although high levels of some hydrophobic peptides have been associated with cheese bitterness (Gomez et al., 1997). Free AA are directly involved in cheese taste and serve also as precursors of compounds responsible for flavor and aroma (Yvon and Rijnen, 2001). In blue-veined cheeses, Penicillium roqueforti is a major proteolytic agent, indirectly because of lactic acid consumption, which brings about a rise in cheese $\mathrm{pH}$ favorable for many chemical reactions, and directly due to its highly active extracellular proteinases (Gripon et al., 1977).

As ripening continues during storage, distribution, and retail, the cheese purchased by the consumer may be of a stronger or different flavor than the manufacturer intended (Wick et al., 2004). Cheeses suffering extensive proteolysis are particularly prone to undesirable effects such as over-ripening associated to off-flavor development, which bring about shorter product shelflife. In addition, the free AA generated at high levels in strongly proteolyzed cheeses may serve as substrates for bacterial decarboxylases, resulting in the accumulation of biogenic amines (BA), a group of compounds of notable public health significance (Silla Santos, 1996). Tyramine is a potent vasoconstrictor with an effect on healthy individuals usually limited to headache or migraine, whereas histamine may cause urticaria, hypotension, headache, flushing, and abdominal cramps (Taylor, 1986; Til et al., 1997). In spite of the wide consensus on their toxicity, acceptable levels of BA in foods have not been established in most countries, partly because of the variable sensitivity of individuals 
to these compounds, which may be affected by factors such as alcohol consumption. Concentrations of 100 to $800 \mathrm{mg}$ of tyramine per kilogram and $30 \mathrm{mg}$ of phenylethylamine per kilogram have been suggested as toxic (ten Brink et al., 1990), but only an upper limit of 100 mg of histamine per kilogram has been set for fish and fish products.

Monoamines tyramine, phenylethylamine, histamine, and tryptamine are respectively formed through the decarboxylation of tyrosine, phenylalanine, histidine, and tryptophan, whereas diamines cadaverine and putrescine derive from lysine and ornithine or arginine via agmatine (Silla Santos, 1996). Enterococci are generally considered the main tyramine formers and heterofermentative lactobacilli the main producers of histamine, but other cheese-borne bacteria may be also involved in BA formation in cheese (Edwards and Sandine, 1981; Joosten and Northolt, 1987; Pircher et al., 2007).

Even though milk hygienization procedures, such as bactofugation and pasteurization, lower the levels of decarboxylase-positive bacteria, postpasteurization contamination of milk and curd by adventitious bacteria-harboring AA decarboxylases, and their subsequent growth and metabolic activity during cheese ripening, usually results in BA buildup. High-pressure (HP) treatments efficiently inactivate microbial contaminants in milk and cheese (O'Reilly et al., 2000; Arqués et al., 2006). They offer the advantage of application after cheese manufacture, when the contamination of the cheese interior is no longer possible, with the only exception being blue-veined cheeses, which are pierced some days after manufacture. The effect of HP treatments on the characteristics of cheeses made from bovine milk (O'Reilly et al., 2003; Evert-Arriagada et al., 2012), ovine milk (Arqués et al., 2007; Juan et al., 2007), and caprine milk (Saldo et al., 2002; Delgado et al., 2012) has been investigated. Pressurization may also be useful to impede BA formation during cheese ripening. To our knowledge, HP treatments with this objective have been assayed only on a pasteurized goat milk cheese, but BA contents of control cheese in the experiment were so low that it was not possible to establish differences with respect to the pressurized cheese (Novella-Rodríguez et al., 2002).

The effect of HP treatments on the chemical characteristics of blue-veined cheeses has been studied only on an Irish cow milk blue cheese, which was pressurized on d 42 of ripening and stored afterward at $4^{\circ} \mathrm{C}$ for $28 \mathrm{~d}$ (Voigt et al., 2010). However, no information is available on the effect of HP treatments on BA formation in blue-veined cheeses. Moreover, the effect of pressurization on the characteristics of ovine milk blueveined cheeses, which include reputed varieties such as
Roquefort, has not been studied. The objective of the present work was to investigate the effect of HP treatments at 400 or $600 \mathrm{MPa}$, applied after 3, 6 or 9 wk of ripening, on the primary and secondary proteolysis, the formation of BA, and the sensory characteristics of ovine milk blue-veined cheese.

\section{MATERIALS AND METHODS}

\section{Cheese-Making and HP Treatments}

Pasteurized $\left(73^{\circ} \mathrm{C}\right.$ for $\left.16 \mathrm{~s}\right)$ ovine milk was used for the manufacture of blue-veined cheese in duplicate trials carried out on consecutive days. Lactic cultures (Flora Danica, 120 g; Chr. Hansen, Tres Cantos, Spain), P. roqueforti (Choozit PA, 1 dose; Danisco, Sassenage, France), and $\mathrm{CaCl}_{2}$ (120 g, in aqueous solution) were added to milk. Milk $(1,200 \mathrm{~L})$ was coagulated at $32^{\circ} \mathrm{C}$ for 35 min with animal rennet (Naturen Premium, 200 $\mathrm{mL}$; Chr. Hansen). Curd was cut into $1.5-\mathrm{cm}$ cubes and held at $32^{\circ} \mathrm{C}$ for $20 \mathrm{~min}$. Whey was drained out and the nonpressed curd was distributed into cylindrical molds. Cheeses, $18 \mathrm{~cm}$ in diameter and $10 \mathrm{~cm}$ high, were turned over 5 times while held at $21^{\circ} \mathrm{C}$ for $24 \mathrm{~h}$, followed by another $48 \mathrm{~h}$ at $15^{\circ} \mathrm{C}$. Afterward, they were salted by rubbing dry salt onto all the surfaces and pierced from the 2 flat surfaces. Ripening took place at $10^{\circ} \mathrm{C}$ and $93 \%$ relative humidity until d 30 and at $5{ }^{\circ} \mathrm{C}$ from d 30 to d 90 . Refrigerated storage at $3^{\circ} \mathrm{C}$ lasted until d 360 .

Cheeses from each trial were pressurized for $5 \mathrm{~min}$ at 400 or $600 \mathrm{MPa}$ after ripening for 3,6 or 9 wk and coded as 400W3, 600W3, 400W6, 600W6, 400W9, and $600 \mathrm{~W} 9$, respectively. Before HP treatments, cheeses were vacuum-packaged in CN300 bags (Cryovac Grace S.A., Barcelona, Spain). A 120-L capacity isostatic press (NC Hyperbaric, Burgos, Spain) was used for HP treatments. Come-up times to reach 400 and $600 \mathrm{MPa}$ were 1.82 and 2.65 min and depressurization times were 6 and $8 \mathrm{~s}$, respectively. Temperature of the water used as transmitting fluid remained under $13^{\circ} \mathrm{C}$ during the process. After HP treatments cheeses were unpackaged, ripening and storage proceeded under the same conditions as for control cheese. A total of 44 cheeses per trial (1 per treatment and sampling date) were used for analytical determinations.

\section{Microbiological Analyses}

Representative cheese samples (10 g) were homogenized with $90 \mathrm{~mL}$ of a sterile $2 \%$ (wt/vol) sodium citrate solution at $45^{\circ} \mathrm{C}$ in a Colworth Stomacher 400 (A. J. Seward Ltd., London, UK). Decimal dilutions of samples were prepared in sterile $0.1 \%$ peptone 
solution. Total viable counts, LAB, enterococci, and lactobacilli were determined in duplicate on plates of PCA (Biolife, Milano, Italy) incubated for $48 \mathrm{~h}$ at $30^{\circ} \mathrm{C}$, M17 agar (acidified at pH 5.7 with acetic acid; Biolife) incubated for $48 \mathrm{~h}$ at $30^{\circ} \mathrm{C}$, KF Streptococcus agar (Oxoid, Basingstoke, UK) incubated for $48 \mathrm{~h}$ at $37^{\circ} \mathrm{C}$, and Rogosa agar (acidified at $\mathrm{pH} 5.4$ with acetic acid; Biolife) incubated anaerobically for $48 \mathrm{~h}$ at $37^{\circ} \mathrm{C}$, respectively. Micrococcaceae were determined in duplicate on plates of mannitol salt agar (Oxoid) incubated for $72 \mathrm{~h}$ at $30^{\circ} \mathrm{C}$, coagulase-positive staphylococci were determined on Baird-Parker agar (Oxoid) with RPF Supplement II (Biolife) incubated at $37^{\circ} \mathrm{C}$ for $48 \mathrm{~h}$, gram-negative bacteria were determined on McConkey agar (Biolife) incubated for $24 \mathrm{~h}$ at $30^{\circ} \mathrm{C}$, and coliforms were determined on VRBA agar (Oxoid) incubated for $24 \mathrm{~h}$ at $37^{\circ} \mathrm{C}$. Molds and yeasts were determined in duplicate on plates of Chloramphenicol Glucose Agar (Scharlab, Barcelona, Spain) incubated for $72 \mathrm{~h}$ at $25^{\circ} \mathrm{C}$. Microbial counts were expressed in log cfu per gram of cheese.

\section{Physicochemical and Enzymatic Determinations}

Proteins were analyzed by capillary gel electrophoresis according to a previously described method (Garde et al., 2002), with some modifications, on an automated P/ACE MDQ capillary electrophoresis apparatus controlled by a 32 Karat Software (Beckman Instruments España S.A., Madrid, Spain). Briefly, $5 \mathrm{~g}$ of cheese were mixed with $25 \mathrm{~mL}$ of $2 \%$ sodium citrate solution and homogenized for $1 \mathrm{~min}$ in an Ultra-Turrax T-10 blender (IKA, Staufen, Germany) at high speed on ice. Twenty microliters of cheese homogenate was mixed with 170 $\mu \mathrm{L}$ of $100 \mathrm{~m} M$ Tris- $\mathrm{HCl}$ buffer ( $\mathrm{pH}$ 9.0) containing $1 \%$ SDS, $10 \mu \mathrm{L}$ of 2-mercaptoethanol, and $4 \mu \mathrm{L}$ of a 10 $\mathrm{kDa}$ internal standard (Beckman Instruments España S.A.), and heated at $95^{\circ} \mathrm{C}$ for $10 \mathrm{~min}$ before injection at $5 \mathrm{kV}$. Electrophoretic separation was performed at 15 $\mathrm{kV}$ for 30 min after a 4-min ramp in a bare-fused silica capillary column (Beckman Instruments España S.A.) of $50 \mu \mathrm{m}$ internal diameter and $30 \mathrm{~cm}$ total length, in SDS-buffer gel (Beckman Instruments España S.A.). To calculate the molecular weight of peaks monitored at $214 \mathrm{~nm}$, the coefficient of relative time mobility to the internal standard was compared with those of a mixture of 10,20,35, 50,100,150, and $225 \mathrm{kDa}$ protein standards (SDS-molecular weight protein size standard; Beckman Instruments España S.A.). Commercial standards (Sigma-Aldrich, Alcobendas, Spain) of bovine $\alpha-\mathrm{CN}, \beta-\mathrm{CN}, \kappa-\mathrm{CN}, \alpha-\mathrm{LA}, \beta-\mathrm{LG}$, serum albumin, and lactoferrin were used for the identification of proteins. Protein peaks were quantified with respect to the in- ternal standard area and expressed as milligrams of protein per grams of cheese DM.

Hydrophilic and hydrophobic peptides in the watersoluble fraction of cheese were determined on duplicate samples by reverse-phase HPLC according to a previously described method (Lau et al., 1991), using a Beckman System Gold chromatograph (Beckman Instruments España S.A.) equipped with a diode array detector module 168 with detection wavelength at 280 $\mathrm{nm}$. Peaks with retention times from 5.5 to $14.6 \mathrm{~min}$ were considered to correspond to hydrophilic peptides and those with retention times from 14.6 to $20.5 \mathrm{~min}$ to hydrophobic peptides. Results were expressed in arbitrary units (AU), calculated as units of chromatogram area per milligram of cheese DM.

Free AA and BA were simultaneously extracted from duplicate samples according to a previously described method (Krause et al., 1995). Analysis of individual free AA was carried out by reverse-phase HPLC after derivatization with Waters AccQ Fluor Reagent, using a Waters AccQ Tag (Waters, Milford, MA) column. Quantitative analysis of individual BA after derivatization with dabsyl chloride was carried out by reversephase HPLC using a System Gold HPLC apparatus (Beckman Coulter, Palo Alto, CA) equipped with a Nova-pack C18 column (Waters). A standard mixture of BA (Sigma-Aldrich) was used for their identification and quantification.

Aminopeptidase activity released into the cheese was measured on duplicate samples of an extract obtained by homogenizing $10 \mathrm{~g}$ of cheese with $20 \mathrm{~mL}$ of $100 \mathrm{mM}$ sodium phosphate buffer, $\mathrm{pH} 7$, at $20^{\circ} \mathrm{C}$ for $2 \mathrm{~min}$ in an Ultra-Turrax T-10 blender, followed by centrifuging $\left(10,000 \times g, 20 \mathrm{~min}, 4^{\circ} \mathrm{C}\right)$ and filtering through Whatman No. 2 paper (GE Healthcare UK Ltd., Buckinghamshire, UK). Lysine $p$-nitroanilide (Lys- $p$-NA) and leucine $p$-nitroanilide (Leu- $p$-NA) were used as substrates. One activity unit corresponds to the activity of enzyme (s) producing $1 \mathrm{nmol}$ of $p$-nitroaniline per minute per gram of cheese.

Overall proteolysis determined by the o-phthaldialdehyde test was analyzed in duplicate, as previously described (Church et al., 1983), and expressed as the absorbance at $340 \mathrm{~nm}$. Cheese DM was determined in triplicate after cheese grinding with sand by drying to a constant weight in an oven at $102^{\circ} \mathrm{C}$. Cheese $\mathrm{pH}$ was measured in triplicate directly by means of a Crison penetration electrode (model 52-3,2; Crison Instruments S.A., Barcelona, Spain) coupled to a Crison GPL $22 \mathrm{pH}$-meter. A cheese sag index was defined and calculated as the percentage of sagging in the central point of the flat surface with respect to the height at the edge of the cheese. 


\section{Sensory Evaluation}

Fifteen trained panelists evaluated the cheeses on d 90, 180, 240, and 360 for flavor quality (overall acceptance), flavor intensity (overall intensity), and the flavor attributes acid, bitter, salty, sweet, and umami on a 0- to 10-point scale, using a horizontal line anchored in the middle and at both ends, as previously described (Garde et al., 2006). Cheeses were cut in representative triangular slices $(15-20 \mathrm{~g})$, which were held for $2 \mathrm{~h}$ at 20 to $22^{\circ} \mathrm{C}$ before sensory evaluation. Four cheeses per session ( 1 control and 3 experimental cheeses, manufactured on the same day), coded with random 3-digit numbers, were randomly presented to panelists. Bread and water were used as rinsing agents between cheeses.

\section{Statistical Treatment}

An ANOVA with HP treatment (6 treatments and control) and ripening time as main effects was performed on the analytical variables by means of SPSS Win 14.0 program (SPSS Inc., Chicago, IL). Calculation of correlations and comparison of means by Tukey's test, with the significance assigned at $P<0.05$, were carried out using the same program.

\section{RESULTS AND DISCUSSION}

\section{Microbial Groups}

Total viable counts and LAB were significantly $(P$ $<0.05)$ affected by HP treatments. Both the pressure level and, at a lesser degree, the ripening time at pressurization influenced mortality rates, which were almost coincident for total viable counts and LAB, an expected result given that $\mathrm{LAB}$ were the predominant microbial group. Counts of LAB, which reached a maximum of $9.54 \log \mathrm{cfu} / \mathrm{g}$ on d 1, decreased by 1.06, 4.69, $0.43,3.98,0.12$, and $3.99 \mathrm{log}$ units in $400 \mathrm{~W} 3,600 \mathrm{~W} 3$, 400W6, 600W6, 400W9, and 600W9 cheeses, respectively, immediately after pressurization with respect to control cheese (data not shown). Counts of LAB recovered by approximately $0.5 \log$ units after treatment at $400 \mathrm{MPa}$, but no recovery was observed in $600 \mathrm{MPa}$ cheeses during the rest of the ripening period. In pressurized Irish blue-veined cheese, counts of lactococci declined by $1.6 \log$ units at $400 \mathrm{MPa}$ and recovered by up to $1.9 \log$ units during storage, whereas at 600 $\mathrm{MPa}$ they declined by $1.9 \mathrm{log}$ units and did not recover during storage (Voigt et al., 2010). In the present work, LAB counts declined during refrigerated storage, from d 90 to 360, in control, 400W6, and 400W9 cheeses, and remained fairly constant in the rest of the cheeses (Table 1), in which the mortality caused by HP treatments had been more marked.

Penicillium roqueforti counts reached $7.73,7.92$, and $7.74 \mathrm{log} \mathrm{cfu} / \mathrm{g}$ on $\mathrm{d} 21,42$, and 63 , respectively. Its population declined by $5.33,0.74$, and $0.71 \mathrm{log}$ units following HP treatment at $400 \mathrm{MPa}$ after 3, 6, and $9 \mathrm{wk}$ of ripening, respectively, and fell below detection level immediately after HP treatment in all $600 \mathrm{MPa}$ cheeses, independently of the day of pressurization (data not shown). Decreases reported for $P$. roqueforti in Irish blue-veined cheese pressurized on d 42 at 400 and 600 MPa were 2.16 and $2.68 \mathrm{log}$ units, respectively (Voigt et al., 2010). The high $P$. roqueforti mortality observed in the present work for HP treatment on d 21 may be ascribed to the physiological status of the strain at that time, with profuse mycelium growth but still with a low level of spores, presumably more baroresistant forms. Underestimation of survivors, in particular of sublethally injured cells when plated on a selective agar, can be also responsible for the low $P$. roqueforti count in 400W3 cheese immediately after treatment on d 21. The differences in P. roqueforti mortality caused by HP treatments on d 42 in both works can be associated to the use of different strains in cheese manufacture. From d 90 onwards, P. roqueforti declined gradually in control and $400 \mathrm{MPa}$ cheeses and was not detected in any of the $600 \mathrm{MPa}$ cheeses (Table 1). The population of non-Penicillium fungi, mostly Geotrichum and yeasts, reached a maximum of $7.07 \log \mathrm{cfu} / \mathrm{g}$ on $\mathrm{d} 42$, and was lowered by $2.91,1.73$, and $0.32 \mathrm{log}$ units in $400 \mathrm{~W} 3$, 400W6, and 400W9 cheeses, respectively, immediately after pressurization with respect to control cheese (data not shown). Similarly to $P$. roquefort $i$, these microorganisms were not detected on d 90 in $600 \mathrm{MPa}$ cheeses. From d 90 onwards, non-Penicillium fungi declined gradually in control cheese and were occasionally detected in pressurized cheeses (Table 1). Yeast counts were not lowered by pressurization in Irish blue-veined cheese treated at $400 \mathrm{MPa}$, and declined by $2.10 \mathrm{log}$ units in cheese treated at $600 \mathrm{MPa}$ (Voigt et al., 2010).

Lactobacilli and enterococci counts were below $5 \mathrm{log}$ $\mathrm{cfu} / \mathrm{g}$ in all cheeses from d 1 to 90 . They remained below $5 \mathrm{log} \mathrm{cfu} / \mathrm{g}$ in control cheese and in cheeses treated at $400 \mathrm{MPa}$ from d 90 to 360 , and were only occasionally detected in $600 \mathrm{MPa}$ cheeses, at levels below $4 \mathrm{log} \mathrm{cfu} / \mathrm{g}$ (data not shown). In Irish blue-veined cheese, counts of nonstarter LAB and enterococci were below $6 \mathrm{log} \mathrm{cfu} / \mathrm{g}$ in control and $400 \mathrm{MPa}$ cheeses, and below $4 \mathrm{log} \mathrm{cfu} / \mathrm{g}$ in $600 \mathrm{MPa}$ cheeses (Voigt et al., 2010). In the present study, Micrococcaceae, staphylococci, gram-negative bacteria, and coliforms were detected occasionally, at counts below $3 \mathrm{log} \mathrm{cfu} / \mathrm{g}$ (data not shown). 
Table 1. Counts ${ }^{1}$ of the main microbial groups in control ovine milk blue cheese and pressurized cheeses

\begin{tabular}{|c|c|c|c|c|c|c|c|c|}
\hline $\begin{array}{l}\text { Microbial } \\
\text { group }\end{array}$ & Days & Control cheese & $400 \mathrm{~W}^{2}$ & $600 \mathrm{~W} 3^{2}$ & $400 \mathrm{~W} 6^{2}$ & $600 \mathrm{~W} 6^{2}$ & $400 \mathrm{~W} 9^{2}$ & $600 \mathrm{~W} 9^{2}$ \\
\hline \multirow[t]{4}{*}{ Lactic acid bacteria } & 90 & $8.24 \pm 0.02^{\mathrm{c}}$ & $6.34 \pm 0.59^{\mathrm{b}}$ & $3.58 \pm 0.39^{\mathrm{a}}$ & $7.98 \pm 0.23^{\mathrm{c}}$ & $4.07 \pm 0.14^{\mathrm{a}}$ & $7.74 \pm 0.03^{\mathrm{c}}$ & $4.08 \pm 0.27^{\mathrm{a}}$ \\
\hline & 180 & $8.02 \pm 0.03^{\mathrm{d}}$ & $6.70 \pm 0.14^{\mathrm{b}}$ & $3.75 \pm 0.04^{\mathrm{a}}$ & $7.46 \pm 0.10^{\mathrm{c}}$ & $3.49 \pm 0.04^{\mathrm{a}}$ & $7.07 \pm 0.05^{\mathrm{bc}}$ & $3.31 \pm 0.31^{\mathrm{a}}$ \\
\hline & 270 & $7.64 \pm 0.06^{\mathrm{d}}$ & $6.71 \pm 0.22^{\mathrm{c}}$ & $4.04 \pm 0.12^{\mathrm{b}}$ & $6.31 \pm 0.30^{\mathrm{c}}$ & $3.15 \pm 0.13^{\mathrm{a}}$ & $6.60 \pm 0.04^{\mathrm{c}}$ & $3.86 \pm 0.16^{\mathrm{al}}$ \\
\hline & 360 & $6.57 \pm 0.13^{\mathrm{c}}$ & $6.41 \pm 0.32^{\mathrm{c}}$ & $3.21 \pm 0.70^{\mathrm{a}}$ & $5.63 \pm 0.02^{\mathrm{b}}$ & $3.33 \pm 0.32^{\mathrm{a}}$ & $5.45 \pm 0.17^{\mathrm{b}}$ & $3.67 \pm 0.06^{\mathrm{a}}$ \\
\hline \multirow[t]{4}{*}{ Penicillium roqueforti } & 90 & $7.53 \pm 0.10^{\mathrm{c}}$ & $5.96 \pm 0.06^{\mathrm{b}}$ & $N D^{3 \mathrm{a}}$ & $5.80 \pm 0.67^{\mathrm{b}}$ & $\mathrm{ND}^{\mathrm{a}}$ & $5.93 \pm 0.04^{\mathrm{b}}$ & $\mathrm{ND}^{\mathrm{a}}$ \\
\hline & 180 & $7.10 \pm 0.04^{\mathrm{d}}$ & $4.36 \pm 0.78^{\mathrm{b}}$ & $\mathrm{ND}^{\mathrm{a}}$ & $5.94 \pm 0.33^{\mathrm{c}}$ & $\mathrm{ND}^{\mathrm{a}}$ & $5.77 \pm 0.07^{\mathrm{c}}$ & $\mathrm{ND}^{\mathrm{a}}$ \\
\hline & 270 & $6.56 \pm 0.23^{\mathrm{d}}$ & $3.24 \pm 0.72^{\mathrm{b}}$ & $\mathrm{ND}^{\mathrm{a}}$ & $5.61 \pm 0.22^{\mathrm{c}}$ & $\mathrm{ND}^{\mathrm{a}}$ & $5.07 \pm 0.47^{\mathrm{c}}$ & $\mathrm{ND}^{\mathrm{a}}$ \\
\hline & 360 & $5.66 \pm 0.08^{\mathrm{c}}$ & $2.79 \pm 0.46^{\mathrm{b}}$ & $\mathrm{ND}^{\mathrm{a}}$ & $3.38 \pm 0.31^{\mathrm{b}}$ & $\mathrm{ND}^{\mathrm{a}}$ & $2.61 \pm 0.36^{\mathrm{b}}$ & $\mathrm{ND}^{\mathrm{a}}$ \\
\hline \multirow{4}{*}{ Non-Penicillium fungi } & 90 & $5.19 \pm 0.76^{\mathrm{c}}$ & $4.11 \pm 0.47^{\mathrm{c}}$ & $\mathrm{ND}^{\mathrm{a}}$ & $4.71 \pm 0.22^{\mathrm{c}}$ & $\mathrm{ND}^{\mathrm{a}}$ & $2.73 \pm 0.42^{\mathrm{b}}$ & $\mathrm{ND}^{\mathrm{a}}$ \\
\hline & 180 & $4.02 \pm 0.45^{\mathrm{b}}$ & $3.65 \pm 0.38^{\mathrm{b}}$ & $3.14 \pm 0.36^{\mathrm{b}}$ & $\mathrm{ND}^{\mathrm{a}}$ & $\mathrm{ND}^{\mathrm{a}}$ & $\mathrm{ND}^{\mathrm{a}}$ & $\mathrm{ND}^{\mathrm{a}}$ \\
\hline & 270 & $3.49 \pm 0.60^{\mathrm{bc}}$ & $4.05 \pm 1.19^{\mathrm{c}}$ & $2.48 \pm 0.28^{\mathrm{b}}$ & $\mathrm{ND}^{\mathrm{a}}$ & $\mathrm{ND}^{\mathrm{a}}$ & $3.13 \pm 0.66^{\mathrm{bc}}$ & $\mathrm{ND}^{\mathrm{a}}$ \\
\hline & 360 & $\mathrm{ND}^{\mathrm{a}}$ & $3.64 \pm 0.46^{\mathrm{b}}$ & $\mathrm{ND}^{\mathrm{a}}$ & $\mathrm{ND}^{\mathrm{a}}$ & $\mathrm{ND}^{\mathrm{a}}$ & $\mathrm{ND}^{\mathrm{a}}$ & $2.73 \pm 0.65^{\mathrm{b}}$ \\
\hline
\end{tabular}

${ }^{\mathrm{a}-\mathrm{d}}$ Means in the same row followed by different superscripts differ $(P<0.05)$.

${ }^{1}$ Mean $\pm \mathrm{SE}(\mathrm{n}=4)$ of duplicate determinations in 2 cheese-making experiments. Microbial counts are expressed as log colony-forming units per gram of cheese.

${ }^{2}$ Treatments were pressurized at $400 \mathrm{MPa}$ after $3 \mathrm{wk}$ of ripening (400W3), $600 \mathrm{MPa}$ after $3 \mathrm{wk}$ (600W3), $400 \mathrm{MPa}$ after $6 \mathrm{wk}$ (400W6), $600 \mathrm{MPa}$ after 6 wk (600W6), 400 MPa after 9 wk (400W9), and $600 \mathrm{MPa}$ after 9 wk (600W9).

${ }^{3} \mathrm{ND}=$ not detected.

Table 2. Values of $\mathrm{pH}, \mathrm{DM}$, and sag index in control ovine milk blue cheese and pressurized cheeses

\begin{tabular}{|c|c|c|c|c|c|c|c|c|}
\hline Item & Days & Control cheese & $400 \mathrm{~W} 3^{1}$ & $600 \mathrm{~W} 3^{1}$ & $400 \mathrm{~W} 6^{1}$ & $600 \mathrm{~W} 6^{1}$ & $400 \mathrm{~W} 9^{1}$ & $600 \mathrm{~W} 9^{1}$ \\
\hline \multirow{4}{*}{ Cheese $\mathrm{pH}^{2}$} & 90 & $5.86 \pm 0.06^{\mathrm{b}}$ & $5.29 \pm 0.04^{\mathrm{a}}$ & $5.24 \pm 0.06^{\mathrm{a}}$ & $5.62 \pm 0.05^{\mathrm{b}}$ & $5.80 \pm 0.06^{\mathrm{b}}$ & $5.67 \pm 0.04^{\mathrm{b}}$ & $5.70 \pm 0.04^{\mathrm{b}}$ \\
\hline & 180 & $5.47 \pm 0.02^{\mathrm{c}}$ & $5.09 \pm 0.02^{\mathrm{a}}$ & $5.01 \pm 0.01^{\mathrm{a}}$ & $5.38 \pm 0.02^{\mathrm{bc}}$ & $5.43 \pm 0.02^{\mathrm{bc}}$ & $5.35 \pm 0.02^{\mathrm{b}}$ & $5.35 \pm 0.03^{\mathrm{b}}$ \\
\hline & 270 & $5.26 \pm 0.01^{\mathrm{cd}}$ & $5.11 \pm 0.04^{\mathrm{b}}$ & $4.94 \pm 0.01^{\mathrm{a}}$ & $5.23 \pm 0.02^{\mathrm{c}}$ & $5.19 \pm 0.03^{\mathrm{bc}}$ & $5.34 \pm 0.03^{\mathrm{d}}$ & $5.27 \pm 0.02^{\mathrm{cd}}$ \\
\hline & 360 & $5.34 \pm 0.01^{\mathrm{c}}$ & $5.15 \pm 0.04^{\mathrm{b}}$ & $5.06 \pm 0.02^{\mathrm{a}}$ & $5.36 \pm 0.02^{\mathrm{c}}$ & $5.38 \pm 0.02^{\mathrm{c}}$ & $5.34 \pm 0.01^{\mathrm{c}}$ & $5.40 \pm 0.01^{\mathrm{c}}$ \\
\hline \multirow{4}{*}{$\mathrm{DM}(\%)^{2}$} & 90 & $53.95 \pm 0.54^{\mathrm{a}}$ & $53.27 \pm 0.75^{\mathrm{a}}$ & $53.86 \pm 0.50^{\mathrm{a}}$ & $52.06 \pm 0.74^{\mathrm{a}}$ & $54.46 \pm 0.42^{\mathrm{a}}$ & $53.67 \pm 0.31^{\mathrm{a}}$ & $52.75 \pm 1.13^{\mathrm{a}}$ \\
\hline & 180 & $54.43 \pm 0.36^{\mathrm{ab}}$ & $52.95 \pm 0.47^{\mathrm{a}}$ & $52.98 \pm 0.30^{\mathrm{a}}$ & $53.39 \pm 1.03^{\mathrm{ab}}$ & $54.61 \pm 0.70^{\mathrm{ab}}$ & $54.85 \pm 0.78^{\mathrm{ab}}$ & $55.05 \pm 0.43^{\mathrm{b}}$ \\
\hline & 270 & $53.16 \pm 0.69^{\mathrm{a}}$ & $54.40 \pm 0.61^{\mathrm{a}}$ & $55.08 \pm 0.19^{\mathrm{a}}$ & $54.10 \pm 0.76^{\mathrm{a}}$ & $53.59 \pm 0.84^{\mathrm{a}}$ & $55.23 \pm 0.44^{\mathrm{a}}$ & $53.99 \pm 0.80^{\mathrm{a}}$ \\
\hline & 360 & $53.35 \pm 0.27^{\mathrm{ab}}$ & $53.60 \pm 0.79^{\mathrm{ab}}$ & $55.16 \pm 0.57^{\mathrm{b}}$ & $54.49 \pm 1.16^{\mathrm{ab}}$ & $52.96 \pm 0.28^{\mathrm{a}}$ & $54.54 \pm 0.73^{\mathrm{ab}}$ & $54.46 \pm 0.46^{\mathrm{ab}}$ \\
\hline \multirow{4}{*}{ Sag index $x^{2,3}$} & 90 & $15.04 \pm 1.08^{\mathrm{a}}$ & $36.24 \pm 1.43^{\mathrm{c}}$ & $34.21 \pm 0.35^{\mathrm{c}}$ & $27.16 \pm 1.63^{\mathrm{b}}$ & $25.49 \pm 0.74^{\mathrm{b}}$ & $30.25 \pm 1.99^{\mathrm{bc}}$ & $29.22 \pm 0.47^{\mathrm{bc}}$ \\
\hline & 180 & $13.51 \pm 0.49^{\mathrm{a}}$ & $32.15 \pm 0.52^{\mathrm{d}}$ & $29.45 \pm 1.27^{\mathrm{cd}}$ & $26.10 \pm 0.78^{\mathrm{bc}}$ & $21.62 \pm 1.72^{\mathrm{b}}$ & $23.92 \pm 1.16^{\mathrm{bc}}$ & $30.09 \pm 0.66^{\mathrm{cd}}$ \\
\hline & 270 & $14.84 \pm 0.80^{\mathrm{a}}$ & $31.94 \pm 0.73^{\mathrm{c}}$ & $28.30 \pm 1.07^{\mathrm{bc}}$ & $23.28 \pm 0.78^{\mathrm{b}}$ & $22.92 \pm 1.49^{\mathrm{b}}$ & $28.03 \pm 1.35^{\mathrm{bc}}$ & $27.96 \pm 1.07^{\mathrm{bc}}$ \\
\hline & 360 & $15.14 \pm 0.56^{\mathrm{a}}$ & $31.78 \pm 1.75^{\mathrm{d}}$ & $30.49 \pm 1.54^{\mathrm{cd}}$ & $24.06 \pm 1.46^{\mathrm{b}}$ & $21.68 \pm 2.94^{\mathrm{b}}$ & $24.61 \pm 1.06^{\mathrm{bc}}$ & $23.23 \pm 1.55^{\mathrm{b}}$ \\
\hline
\end{tabular}

${ }^{\mathrm{a}-\mathrm{d}}$ Means in the same row followed by different superscripts differ $(P<0.05)$.

${ }^{1}$ Treatments were pressurized at $400 \mathrm{MPa}$ after $3 \mathrm{wk}$ of ripening (400W3), $600 \mathrm{MPa}$ after 3 wk (600W3), $400 \mathrm{MPa}$ after 6 wk (400W6), $600 \mathrm{MPa}$ after 6 wk (600W6), 400 MPa after $9 \mathrm{wk}(400 \mathrm{~W} 9)$, and $600 \mathrm{MPa}$ after $9 \mathrm{wk}(600 \mathrm{~W} 9)$.

${ }^{2}$ Mean \pm SE $(n=6)$ of triplicate determinations in 2 cheese-making experiments.

${ }^{3}$ Cheese sag index was calculated as 100 - (100 height at the central point/height at the edge). 


\section{Cheese $\mathrm{pH}, \mathrm{DM}$, and Sag Index}

Control cheese $\mathrm{pH}$, which had declined to 4.76 on d 1 , fell further to 4.63 by d 7 , and rose afterward gradually to values of 5.65 on d 21, 6.10 on d 42 , and 6.24 on d 63 (data not shown), most likely because of lactic acid consumption by molds and yeasts. This $\mathrm{pH}$ pattern is similar to that recorded for Stilton cheese (Madkor et al., 1987). In pressurized cheeses, $\mathrm{pH}$ values immediately after HP treatments were similar to those recorded for the respective control cheeses, with differences always under $0.2 \mathrm{pH}$ units. However, the $\mathrm{pH}$ evolved differently during ripening of $400 \mathrm{~W} 3$ and $600 \mathrm{~W} 3$ cheeses than in the rest, with significantly $(P<0.05)$ lower values on d 90 in cheeses pressurized after $3 \mathrm{wk}$ of ripening, most probably because of impaired lactic acid consumption by damaged $P$. roqueforti cells (Table 2 ). Dry matter of control cheese, which was $46.63 \%$ on d 1, increased to 50.73 and $52.97 \%$ on $d 21$ and 63 (data not shown), respectively, and to $53.95 \%$ on d 90 (Table 2). During refrigerated storage, DM remained fairly constant, with differences between cheeses under $3 \%$ at all sampling times.

The sag index, measuring the subsiding at the central point of the flat surface with respect to height at the edge, was significantly $(P<0.05)$ higher in all the pressurized cheeses, independently of the pressure level or the ripening time at pressurization, than in control cheese (Table 2). The sag index of control cheese did not vary during refrigerated storage, whereas gradual shape recovery took place in all the pressurized cheeses from d 90 to 360 , with increases in the sag index ranging from 3.1 to $6.0 \%$.

\section{Proteolysis}

Changes in the concentration of proteins from milk to 1-d-old cheese can be explained by losses during whey drainage and by enzymatic hydrolysis. Losses in whey were responsible for the decline observed in the contents of the water-soluble proteins $\alpha$-LA, $\beta$-LG, and serum albumin from milk to 1 -d-old cheese (Table 3 ). In the absence of proteolysis, contents of $\alpha-\mathrm{CN}, \beta-\mathrm{CN}$, and $\kappa$-CN should have increased from milk to 1-d-old cheese, due to the retention and concentration of $\mathrm{CN}$ micelles in the curd. However, because of the activity of rennet and starter proteinases the contents of $\alpha-\mathrm{CN}, \beta-\mathrm{CN}$, and $\kappa$-CN referred to DM declined by 65,11 , and $71 \%$ (Table 3), respectively, from milk to 1 -d-old cheese. On d $90, \alpha-C N$ and $\kappa-C N$ were no longer detectable in control cheese, whereas $\beta-\mathrm{CN}$ was 99\% lower and para-k-CN $79 \%$ lower than on $\mathrm{d} 1$. A more rapid hydrolysis of $\alpha-\mathrm{CN}$ than of $\beta-\mathrm{CN}$ was also recorded for Stilton cheese (Madkor et al., 1987). The only whey protein detected on d 90 in control cheese was $\beta$-LG, at a level $99 \%$ lower than on d 1 (Table 3 ). Considerably higher levels of residual $\alpha-\mathrm{CN}$ and $\beta-\mathrm{CN}$ are found in non-Penicillium ripened cheeses (Gomez et al., 1999). In addition to the rennet and starter LAB proteinases acting in most cheese varieties, $P$. roqueforti proteinases (Modler et al., 1974; Trieu-Cuot et al., 1982) were most likely responsible for the intense proteolysis observed during ripening of blue-veined cheese in the present work. During the refrigerated storage period proteolysis still progressed. Thus, $\beta-\mathrm{CN}$ and para- $\kappa-\mathrm{CN}$ declined from d 90 to 360 in control cheese by 96 and $80 \%$, respectively, and $\gamma-\mathrm{CN}$, the degradation products resulting from primary proteolysis, by $81 \%$ (Table 4). From d 90 onwards, the highest levels of $\beta-\mathrm{CN}$, para- $\kappa-\mathrm{CN}$, and $\gamma-\mathrm{CN}$ were generally found in the $600 \mathrm{~W} 3$ cheese. Protein concentrations in all cheeses during refrigerated storage were at such low levels, with the exception of $\gamma-\mathrm{CN}$, that a significant contribution of residual proteins to the formation of peptides and free AA at this stage is to be precluded. A less pronounced proteolysis, as shown by the lower $\mathrm{pH}$ 4.6- and TCA-soluble $\mathrm{N}$ contents, was recorded for Irish blue-veined cheese pressurized at $600 \mathrm{MPa}$ than for control cheese or for $400 \mathrm{MPa}$ cheese (Voigt et al., 2010). The lower proteolysis in cheeses treated at 600 MPa can be ascribed to a lower activity of chymosin and, probably, of $P$. roqueforti proteinases. Chymosin is partially inactivated by pressurization at $400 \mathrm{MPa}$ or higher pressures, but plasmin, a more baroresistant enzyme, maintains full activity after pressurization at 500 or $600 \mathrm{MPa}$ (Malone et al., 2003; Juan et al., 2007). To our knowledge, no information is available on the barotolerance of $P$. roqueforti proteinases.

Hydrophilic peptides increased gradually during the ripening of control cheese, with levels attaining 6.79, 24.51, 25.78, and 27.10 AU respectively on d 1, 21, 42 , and 63 , whereas the levels of hydrophobic peptides reached a maximum of $7.48 \mathrm{AU}$ on d 21 (data not shown) and declined thereafter to 5.66 AU on d 90. Both hydrophilic peptides and hydrophobic peptides suffered minor variations from d 90 to 360 (Table 5). In the case of hydrophilic peptides, the differences between control and pressurized cheeses at the same sampling time were generally not significant. However, hydrophobic peptides were generally found at higher levels in pressurized cheeses than in the respective control cheese. Consequently, the hydrophobic peptides-to-hydrophilic peptides ratio, which has been reported to correlate well with cheese bitterness (Gomez et al., 1997), was lower in control cheese than in most of the pressurized cheeses (Table 5). The highest levels of hydrophobic peptides and of the peptide ratio from d 90 to 360 were generally found for the $600 \mathrm{~W} 3$ cheese. Contrary to 
Table 3. Main proteins ${ }^{1}$ in milk and control ovine milk blue cheese during ripening

\begin{tabular}{|c|c|c|c|c|c|c|c|c|}
\hline Days & $\alpha-\mathrm{CN}$ & $\beta-\mathrm{CN}$ & $\kappa-\mathrm{CN}$ & para-k-CN & $\gamma-\mathrm{CN}$ & $\alpha-\mathrm{LA}$ & $\beta-\mathrm{LG}$ & $\begin{array}{c}\text { Serum } \\
\text { albumin }\end{array}$ \\
\hline Milk & $59.52 \pm 2.95$ & $205.47 \pm 13.21$ & $15.23 \pm 1.34$ & $\mathrm{ND}^{2}$ & $7.97 \pm 1.26$ & $2.19 \pm 0.10$ & $49.15 \pm 2.65$ & $5.54 \pm 0.67$ \\
\hline 1 & $20.76 \pm 3.69^{\mathrm{c}}$ & $183.67 \pm 19.42^{\mathrm{c}}$ & $4.36 \pm 0.36^{\mathrm{c}}$ & $28.35 \pm 2.34^{\mathrm{c}}$ & $7.95 \pm 1.02^{\mathrm{a}}$ & $0.87 \pm 0.08^{\mathrm{b}}$ & $7.37 \pm 0.79^{\mathrm{b}}$ & $0.80 \pm 0.15^{\mathrm{c}}$ \\
\hline 21 & $1.49 \pm 0.48^{\mathrm{b}}$ & $25.05 \pm 2.44^{\mathrm{b}}$ & $0.95 \pm 0.25^{\mathrm{b}}$ & $15.25 \pm 1.46^{\mathrm{b}}$ & $44.87 \pm 2.80^{\mathrm{c}}$ & $\mathrm{ND}^{\mathrm{a}}$ & $0.21 \pm 0.03^{\mathrm{a}}$ & $0.13 \pm 0.08^{\mathrm{b}}$ \\
\hline 42 & $1.12 \pm 0.21^{\mathrm{b}}$ & $13.38 \pm 1.72^{\mathrm{ab}}$ & $0.43 \pm 0.13^{\mathrm{b}}$ & $9.64 \pm 1.14^{\mathrm{ab}}$ & $32.05 \pm 2.40^{\mathrm{bc}}$ & $\mathrm{ND}^{\mathrm{a}}$ & $0.15 \pm 0.06^{\mathrm{a}}$ & $0.05 \pm 0.03^{\mathrm{b}}$ \\
\hline 63 & $0.54 \pm 0.19^{\mathrm{b}}$ & $6.20 \pm 1.38^{\mathrm{a}}$ & $0.02 \pm 0.01^{\mathrm{b}}$ & $8.22 \pm 0.96^{\mathrm{ab}}$ & $30.05 \pm 3.06^{\mathrm{b}}$ & $\mathrm{ND}^{\mathrm{a}}$ & $0.18 \pm 0.07^{\mathrm{a}}$ & $\mathrm{ND}^{\mathrm{a}}$ \\
\hline 90 & $\mathrm{ND}^{\mathrm{a}}$ & $1.22 \pm 0.35^{\mathrm{a}}$ & $\mathrm{ND}^{\mathrm{a}}$ & $5.94 \pm 0.82^{\mathrm{a}}$ & $19.60 \pm 4.21^{\mathrm{ab}}$ & $\mathrm{ND}^{\mathrm{a}}$ & $0.07 \pm 0.03^{\mathrm{a}}$ & $\mathrm{ND}^{\mathrm{a}}$ \\
\hline
\end{tabular}

${ }^{\mathrm{a}-\mathrm{c}}$ Means for cheese samples on the same column followed by different superscripts differ $(P<0.05)$.

${ }^{1}$ Mean \pm SE $(n=4)$ of duplicate determinations in 2 cheese-making experiments. Proteins are expressed in milligrams per gram of milk or cheese DM.

${ }^{2} \mathrm{ND}=$ not detected.

Table 4. Main caseins ${ }^{1}$ in control ovine milk blue cheese and pressurized cheeses

\begin{tabular}{|c|c|c|c|c|c|c|c|c|}
\hline Casein & Days & Control cheese & $400 \mathrm{~W}^{2}$ & $600 \mathrm{~W} 3^{2}$ & $400 \mathrm{~W} 6^{2}$ & $600 \mathrm{~W} 6^{2}$ & $400 \mathrm{~W} 9^{2}$ & $600 \mathrm{~W} 9^{2}$ \\
\hline \multirow[t]{4}{*}{$\beta-\mathrm{CN}$} & 90 & $1.22 \pm 0.35^{\mathrm{a}}$ & $3.58 \pm 0.84^{\mathrm{b}}$ & $3.22 \pm 0.76^{\mathrm{ab}}$ & $0.63 \pm 0.24^{\mathrm{a}}$ & $2.40 \pm 0.12^{\mathrm{ab}}$ & $0.59 \pm 0.21^{\mathrm{a}}$ & $0.71 \pm 0.14^{\mathrm{a}}$ \\
\hline & 180 & $0.80 \pm 0.22^{\mathrm{ab}}$ & $1.20 \pm 0.20^{\mathrm{ab}}$ & $1.98 \pm 0.30^{\mathrm{b}}$ & $0.62 \pm 0.17^{\mathrm{ab}}$ & $0.66 \pm 0.19^{\mathrm{ab}}$ & $0.33 \pm 0.09^{\mathrm{a}}$ & $0.39 \pm 0.17^{\mathrm{a}}$ \\
\hline & 270 & $0.07 \pm 0.05^{\mathrm{a}}$ & $0.30 \pm 0.11^{\mathrm{ab}}$ & $0.85 \pm 0.26^{\mathrm{b}}$ & $0.16 \pm 0.02^{\mathrm{a}}$ & $0.35 \pm 0.09^{\mathrm{ab}}$ & $0.09 \pm 0.04^{\mathrm{a}}$ & $0.15 \pm 0.05^{\mathrm{a}}$ \\
\hline & 360 & $0.05 \pm 0.03^{\mathrm{a}}$ & $0.13 \pm 0.06^{\mathrm{ab}}$ & $0.17 \pm 0.04^{\mathrm{ab}}$ & $0.16 \pm 0.07^{\mathrm{ab}}$ & $0.32 \pm 0.09^{\mathrm{b}}$ & $0.07 \pm 0.03^{\mathrm{ab}}$ & $0.09 \pm 0.02^{\mathrm{a}}$ \\
\hline \multirow[t]{4}{*}{ para-к-CN } & 90 & $5.94 \pm 0.82^{\mathrm{a}}$ & $5.71 \pm 1.12^{\mathrm{a}}$ & $6.41 \pm 0.77^{\mathrm{a}}$ & $3.15 \pm 0.62^{\mathrm{a}}$ & $6.00 \pm 0.68^{\mathrm{a}}$ & $3.68 \pm 0.83^{\mathrm{a}}$ & $4.84 \pm 0.30^{\mathrm{a}}$ \\
\hline & 180 & $3.50 \pm 0.95^{\mathrm{ab}}$ & $2.94 \pm 0.31^{\mathrm{ab}}$ & $4.54 \pm 0.65^{\mathrm{b}}$ & $2.56 \pm 0.29^{\mathrm{ab}}$ & $3.97 \pm 0.47^{\mathrm{ab}}$ & $1.65 \pm 0.49^{\mathrm{a}}$ & $2.60 \pm 0.40^{\mathrm{ab}}$ \\
\hline & 270 & $1.28 \pm 0.22^{\mathrm{ab}}$ & $1.43 \pm 0.18^{\mathrm{abc}}$ & $2.95 \pm 0.62^{\mathrm{c}}$ & $0.60 \pm 0.18^{\mathrm{a}}$ & $2.29 \pm 0.29^{\mathrm{bc}}$ & $0.91 \pm 0.28^{\mathrm{ab}}$ & $1.71 \pm 0.61^{\mathrm{abc}}$ \\
\hline & 360 & $1.16 \pm 0.24^{\mathrm{ab}}$ & $1.31 \pm 0.29^{\mathrm{ab}}$ & $2.01 \pm 0.35^{\mathrm{b}}$ & $0.75 \pm 0.16^{\mathrm{a}}$ & $1.21 \pm 0.32^{\mathrm{ab}}$ & $0.60 \pm 0.11^{\mathrm{a}}$ & $1.25 \pm 0.08^{\mathrm{ab}}$ \\
\hline \multirow[t]{4}{*}{$\gamma-\mathrm{CN}$} & 90 & $19.60 \pm 3.21^{\mathrm{ab}}$ & $14.41 \pm 2.81^{\mathrm{ab}}$ & $17.24 \pm 2.46^{\mathrm{ab}}$ & $9.99 \pm 1.93^{\mathrm{a}}$ & $22.08 \pm 2.09^{\mathrm{b}}$ & $11.90 \pm 2.18^{\mathrm{a}}$ & $12.31 \pm 0.37^{\mathrm{ab}}$ \\
\hline & 180 & $12.87 \pm 2.92^{\mathrm{ab}}$ & $8.95 \pm 0.53^{\mathrm{ab}}$ & $14.17 \pm 1.97^{\mathrm{b}}$ & $10.10 \pm 1.49^{\mathrm{ab}}$ & $13.14 \pm 0.38^{\mathrm{ab}}$ & $5.92 \pm 1.26^{\mathrm{a}}$ & $8.37 \pm 1.13^{\mathrm{ab}}$ \\
\hline & 270 & $4.66 \pm 0.97^{\mathrm{ab}}$ & $5.50 \pm 0.86^{\mathrm{ab}}$ & $10.42 \pm 1.97^{\mathrm{c}}$ & $2.82 \pm 0.67^{\mathrm{a}}$ & $7.54 \pm 0.75^{\mathrm{bc}}$ & $3.82 \pm 0.52^{\mathrm{ab}}$ & $4.80 \pm 1.23^{\mathrm{ab}}$ \\
\hline & 360 & $3.77 \pm 0.48^{\mathrm{ab}}$ & $3.85 \pm 1.09^{\mathrm{ab}}$ & $6.03 \pm 0.98^{\mathrm{b}}$ & $2.56 \pm 0.29^{\mathrm{a}}$ & $4.80 \pm 0.70^{\mathrm{ab}}$ & $2.79 \pm 0.25^{\mathrm{a}}$ & $5.18 \pm 0.19^{\mathrm{ab}}$ \\
\hline
\end{tabular}

${ }^{\mathrm{a}-\mathrm{c}}$ Means in the same row followed by different superscripts differ $(P<0.05)$.

${ }^{1}$ Mean $\pm \mathrm{SE}(\mathrm{n}=4)$ of duplicate determinations in 2 cheese-making experiments. Caseins are expressed in milligrams per gram of cheese DM. $\alpha$-Casein and $\kappa$-CN were not detected on d 90 and afterward.

${ }^{2}$ Treatments were pressurized at $400 \mathrm{MPa}$ after $3 \mathrm{wk}$ of ripening (400W3), $600 \mathrm{MPa}$ after $3 \mathrm{wk}(600 \mathrm{~W} 3), 400 \mathrm{MPa}$ after 6 wk (400W6), $600 \mathrm{MPa}$ after 6 wk (600W6), 400 MPa after 9 wk (400W9), and $600 \mathrm{MPa}$ after 9 wk (600W9). 
our results, no significant differences in the late-eluting region, corresponding to hydrophobic peptides, were found between control and pressurized Irish blue-veined cheeses (Voigt et al., 2010). The shorter cheese ripening and storage periods in their work may explain the different finding.

Aminopeptidase activity in control cheese reached maximum levels of $24.83 \mathrm{nmol} p$-nitroaniline per minute per gram on d 42 (with Leu- $p$-NA as substrate) and $24.58 \mathrm{nmol} p$-nitroaniline per minute per gram on $\mathrm{d}$ 63 (with Lys- $p$-NA as substrate; data not shown), and then declined during the rest of the ripening period to 19.61 and $19.43 \mathrm{nmol} p$-nitroaniline per minute per gram, respectively, on d 90 (Table 6). Aminopeptidase activity, which originates mostly from starter LAB but also from other added or contaminating microorganisms, was not determined in Irish blue-veined cheese (Voigt et al., 2010). In Gorgonzola cheese, not only aminopeptidase activity but also carboxypeptidase and iminopeptidase activities, attributed to $P$. roquefort $i$ by the authors, increased until d 86, the last sampling date (Gobbetti et al., 1997). High-pressure treatments show differences in the inactivation of bacterial peptidases, depending not only on process parameters, but also on bacterial species and assay substrates, and the effect may vary for different peptidolytic enzymes within a bacterial strain (Malone et al., 2003). In the present work, pressurization lowered aminopeptidase activity by 20 to $30 \%$ at $400 \mathrm{MPa}$ and by 40 to $50 \%$ at 600 $\mathrm{MPa}$ immediately after treatment (data not shown), in agreement with previous results for a nonmoldripened ovine milk cheese (Garde et al., 2007). On d 90, aminopeptidase activity levels were significantly $(P$ $<0.05$ ) lower in all the pressurized cheeses than in control cheese. Aminopeptidase activity declined further during refrigerated storage, to levels under $20 \%$ of the maximum values, and the differences between cheeses persisted until d 360 (Table 6).

Overall proteolysis, as determined by the o-phthaldialdehyde method, increased in control cheese from a value of 0.15 on d 1 to 0.89 on d $21,2.93$ on d $42,5.45$ on d 63 (data not shown), and 6.89 on d 90 (Table 7). Proteolysis values during ripening were considerably higher than those reported for cheese varieties not mold-ripened (Garde et al., 2002, 2007). Proteolysis values in pressurized cheeses immediately after treatment were similar to those of the respective control cheese (data not shown). However, significant $(P<$ $0.05)$ differences in the overall proteolysis values of cheeses were recorded on d 90, the lowest value being that of $600 \mathrm{~W} 3$ cheese (Table 7). During refrigerated storage, overall proteolysis increased by $51 \%$ in control cheese, and by 37 to $68 \%$ in pressurized cheeses. On d 360 , control cheese and cheeses treated at $400 \mathrm{MPa}$ on wk 6 or 9 showed the highest overall proteolysis values, and $600 \mathrm{~W} 3$ cheese the lowest value.

Total free AA concentration increased in control cheese from $1.49 \mathrm{mg} / \mathrm{g}$ of DM on d 1 to $61.20 \mathrm{mg} / \mathrm{g}$ of DM on d 90, a considerably higher concentration than those reported for Gorgonzola cheese and other strongly proteolyzed cheeses of approximately the same ripening time (Gobbetti et al., 1997; Garde et al., 2002, 2007), but lower than the concentration of free AA in Stilton cheese (Madkor et al., 1987). In the present work, free AA concentrations in pressurized cheeses immediately after treatment were close to those of the respective control cheese (data not shown). From d 90 to 360, total free AA increased by $91 \%$ in control cheese and by 59 to $116 \%$ in pressurized cheeses. Similar to the pattern observed for overall proteolysis, the concentration of total free AA during refrigerated storage tended to reach its maximum levels in control cheese and in 400W6 and 400W9 cheeses, probably favored by conformational changes in the $\mathrm{CN}$ of these cheeses that facilitate the access of enzymes to their substrates (O'Reilly et al., 2003), whereas the lowest values were those of 600W3 cheese (Table 7). Early pressurization (after 3 wk of ripening) at a high pressure level $(600 \mathrm{MPa})$ was the most effective treatment in retarding secondary proteolysis, even though the lowest aminopeptidase activity values were not those of $600 \mathrm{~W} 3$ cheese.

Aminopeptidase activities on Leu- $p$-NA and Lys- $p$ $\mathrm{NA}$ as substrates correlated well with each other $\left(\mathrm{r}^{2}\right.$ values $=0.922$ and 0.982 on d 90 and 360, respectively), and this was also true for the correlation of overall proteolysis with total free AA ( $\mathrm{r}^{2}$ values $=0.782$ and 0.942 on d 90 and 360). However, a significant correlation of aminopeptidase activities with overall proteolysis or free AA concentration in cheeses was not observed $\left(\mathrm{r}^{2}\right.$ values $=<0.10$ and $<0.40$ on $\mathrm{d} 90$ and 360 ). It must be taken into account that aminopeptidases were at levels far from their maximum values during refrigerated storage, and also that aminopeptidases present in intact microbial cells not lysed by treatment at 400 $\mathrm{MPa}$, which most likely are not recovered in the cheese extracts used for aminopeptidase assays, contribute to cheese secondary proteolysis too. The low correlation of aminopeptidase activity to overall proteolysis and total free AA can be also attributed to the fact that carboxypeptidase and iminopeptidase activities coming from $P$. roqueforti, which enhance overall proteolysis and participate in free AA formation, were not evaluated when using Leu- $p$-NA and Lys- $p$-NA as substrates.

\section{$B A$}

Histamine, cadaverine, and spermine were not detected at any of the sampling times in any of the 
Table 5. Hydrophilic peptides, hydrophobic peptides, and the hydrophobic-to-hydrophilic peptide ratio in control ovine milk blue cheese and pressurized cheeses

\begin{tabular}{|c|c|c|c|c|c|c|c|c|}
\hline Peptide & Days & Control cheese & $400 \mathrm{~W} 3^{1}$ & $600 \mathrm{~W} 3^{1}$ & $400 \mathrm{~W} 6^{1}$ & $600 \mathrm{~W} 6^{1}$ & $400 \mathrm{~W} 9^{1}$ & $600 \mathrm{~W} 9^{1}$ \\
\hline \multirow[t]{4}{*}{ Hydrophilic peptides ${ }^{2}$} & 90 & $28.16 \pm 0.82^{\mathrm{a}}$ & $36.64 \pm 0.41^{\mathrm{d}}$ & $27.42 \pm 0.63^{\mathrm{a}}$ & $32.58 \pm 0.96^{\mathrm{bc}}$ & $28.91 \pm 1.22^{\mathrm{ab}}$ & $30.70 \pm 0.51^{\mathrm{abc}}$ & $33.00 \pm 0.08^{\mathrm{cd}}$ \\
\hline & 180 & $28.08 \pm 1.49^{\mathrm{a}}$ & $31.76 \pm 0.28^{\mathrm{a}}$ & $29.40 \pm 1.55^{\mathrm{a}}$ & $26.68 \pm 1.14^{\mathrm{a}}$ & $29.20 \pm 0.14^{\mathrm{a}}$ & $27.93 \pm 0.19^{\mathrm{a}}$ & $27.13 \pm 1.66^{\mathrm{a}}$ \\
\hline & 270 & $29.39 \pm 0.55^{\mathrm{ab}}$ & $27.80 \pm 0.35^{\mathrm{ab}}$ & $25.86 \pm 1.23^{\mathrm{a}}$ & $30.19 \pm 1.11^{\mathrm{b}}$ & $27.90 \pm 0.23^{\mathrm{ab}}$ & $30.72 \pm 0.86^{\mathrm{b}}$ & $31.12 \pm 1.05^{\mathrm{b}}$ \\
\hline & 360 & $29.81 \pm 0.87^{\mathrm{ab}}$ & $30.10 \pm 2.73^{\mathrm{ab}}$ & $26.86 \pm 0.11^{\mathrm{a}}$ & $33.11 \pm 0.53^{\mathrm{bc}}$ & $27.55 \pm 0.74^{\mathrm{a}}$ & $36.05 \pm 0.49^{c}$ & $31.93 \pm 0.12^{\mathrm{ab}}$ \\
\hline \multirow{4}{*}{ Hydrophobic peptides ${ }^{2}$} & 90 & $5.66 \pm 0.14^{\mathrm{a}}$ & $9.40 \pm 0.36^{\mathrm{d}}$ & $8.85 \pm 0.36^{\mathrm{cd}}$ & $7.16 \pm 0.20^{\mathrm{b}}$ & $7.72 \pm 0.68^{\mathrm{bc}}$ & $6.73 \pm 0.06^{\mathrm{ab}}$ & $6.70 \pm 0.13^{\mathrm{ab}}$ \\
\hline & 180 & $4.80 \pm 0.19^{\mathrm{a}}$ & $7.61 \pm 0.30^{c}$ & $9.08 \pm 0.55^{\mathrm{d}}$ & $6.11 \pm 0.13^{\mathrm{ab}}$ & $7.12 \pm 0.30^{\mathrm{bc}}$ & $5.88 \pm 0.40^{\mathrm{ab}}$ & $5.24 \pm 0.33^{\mathrm{a}}$ \\
\hline & 270 & $4.44 \pm 0.32^{\mathrm{a}}$ & $4.14 \pm 0.12^{\mathrm{a}}$ & $6.53 \pm 0.26^{\mathrm{bc}}$ & $4.78 \pm 0.96^{\mathrm{ab}}$ & $5.35 \pm 0.49^{\mathrm{ab}}$ & $6.82 \pm 0.35^{\mathrm{bc}}$ & $7.33 \pm 0.22^{\mathrm{c}}$ \\
\hline & 360 & $4.54 \pm 0.18^{\mathrm{a}}$ & $6.54 \pm 0.01^{\mathrm{b}}$ & $8.33 \pm 0.32^{\mathrm{d}}$ & $6.81 \pm 0.49^{\mathrm{bc}}$ & $6.61 \pm 0.16^{\mathrm{b}}$ & $6.93 \pm 0.07^{\mathrm{bc}}$ & $7.85 \pm 0.11^{\mathrm{cd}}$ \\
\hline \multirow[t]{4}{*}{ Ratio $^{2}$} & 90 & $0.20 \pm 0.01^{\mathrm{a}}$ & $0.26 \pm 0.01^{\mathrm{bc}}$ & $0.32 \pm 0.01^{\mathrm{d}}$ & $0.22 \pm 0.01^{\mathrm{ab}}$ & $0.27 \pm 0.01^{\mathrm{c}}$ & $0.22 \pm 0.01^{\mathrm{ab}}$ & $0.20 \pm 0.01^{\mathrm{a}}$ \\
\hline & 180 & $0.17 \pm 0.00^{\mathrm{a}}$ & $0.24 \pm 0.01^{\mathrm{b}}$ & $0.31 \pm 0.03^{\mathrm{c}}$ & $0.23 \pm 0.01^{\mathrm{ab}}$ & $0.24 \pm 0.01^{\mathrm{b}}$ & $0.21 \pm 0.02^{\mathrm{ab}}$ & $0.19 \pm 0.01^{\mathrm{ab}}$ \\
\hline & 270 & $0.15 \pm 0.01^{\mathrm{a}}$ & $0.15 \pm 0.00^{\mathrm{a}}$ & $0.25 \pm 0.00^{\mathrm{b}}$ & $0.16 \pm 0.03^{\mathrm{a}}$ & $0.19 \pm 0.02^{\mathrm{ab}}$ & $0.22 \pm 0.01^{\mathrm{b}}$ & $0.24 \pm 0.02^{\mathrm{b}}$ \\
\hline & 360 & $0.15 \pm 0.01^{\mathrm{a}}$ & $0.22 \pm 0.02^{\mathrm{c}}$ & $0.31 \pm 0.01^{\mathrm{d}}$ & $0.21 \pm 0.01^{\mathrm{bc}}$ & $0.24 \pm 0.01^{\mathrm{c}}$ & $0.19 \pm 0.00^{\mathrm{ab}}$ & $0.25 \pm 0.00^{\mathrm{c}}$ \\
\hline
\end{tabular}

${ }^{\mathrm{a}-\mathrm{d}}$ Means in the same row followed by different superscripts differ $(P<0.05)$.

${ }^{1}$ Treatments were pressurized at $400 \mathrm{MPa}$ after $3 \mathrm{wk}$ of ripening (400W3), $600 \mathrm{MPa}$ after 3 wk (600W3), $400 \mathrm{MPa}$ after 6 wk (400W6), $600 \mathrm{MPa}$ after 6 wk (600W6), 400 MPa after 9 wk (400W9), and $600 \mathrm{MPa}$ after 9 wk (600W9).

${ }^{2}$ Mean \pm SE $(n=4)$ of duplicate determinations in 2 cheese-making experiments. Peptides, determined at $280 \mathrm{~nm}$, are expressed in arbitrary units (AU), calculated as units of chromatogram area per milligram of cheese DM.

Table 6. Aminopeptidase activity on Leu- $p$-NA and Lys- $p$-NA in control ovine milk blue cheese and pressurized cheeses

\begin{tabular}{|c|c|c|c|c|c|c|c|c|}
\hline Aminopeptidase activity & Days & Control cheese & $400 \mathrm{~W} 3^{1}$ & $600 \mathrm{~W} 3^{1}$ & $400 \mathrm{~W} 6^{1}$ & $600 \mathrm{~W} 6^{1}$ & $400 \mathrm{~W} 9^{1}$ & $600 \mathrm{~W} 9^{1}$ \\
\hline \multirow[t]{4}{*}{ Activity on Leu- $p$-NA ${ }^{2}$} & 90 & $19.61 \pm 0.99^{\mathrm{d}}$ & $12.34 \pm 0.31^{\mathrm{c}}$ & $11.34 \pm 0.27^{\mathrm{bc}}$ & $7.58 \pm 0.12^{\mathrm{a}}$ & $11.55 \pm 0.70^{\mathrm{bc}}$ & $11.39 \pm 0.72^{\mathrm{bc}}$ & $8.19 \pm 0.32^{\mathrm{ab}}$ \\
\hline & 180 & $6.66 \pm 0.48^{\mathrm{d}}$ & $4.38 \pm 0.21^{\mathrm{bc}}$ & $4.77 \pm 0.52^{\mathrm{c}}$ & $3.25 \pm 0.52^{\mathrm{ab}}$ & $2.63 \pm 0.31^{\mathrm{a}}$ & $2.86 \pm 0.07^{\mathrm{ab}}$ & $2.65 \pm 0.05^{\mathrm{a}}$ \\
\hline & 270 & $5.30 \pm 0.83^{\mathrm{c}}$ & $2.31 \pm 0.07^{\mathrm{b}}$ & $2.34 \pm 0.15^{\mathrm{b}}$ & $1.44 \pm 0.07^{\mathrm{a}}$ & $1.42 \pm 0.01^{\mathrm{a}}$ & $2.13 \pm 0.10^{\mathrm{b}}$ & $1.21 \pm 0.01^{\mathrm{a}}$ \\
\hline & 360 & $3.26 \pm 0.27^{\mathrm{c}}$ & $1.11 \pm 0.18^{\mathrm{a}}$ & $1.39 \pm 0.05^{\mathrm{ab}}$ & $1.85 \pm 0.08^{\mathrm{b}}$ & $0.92 \pm 0.06^{\mathrm{a}}$ & $1.77 \pm 0.04^{\mathrm{b}}$ & $0.89 \pm 0.12^{\mathrm{a}}$ \\
\hline \multirow{4}{*}{ Activity on Lys- $p$-NA ${ }^{2}$} & 90 & $19.43 \pm 0.48^{\mathrm{e}}$ & $10.92 \pm 0.61^{\mathrm{cd}}$ & $9.48 \pm 0.34^{\mathrm{abc}}$ & $8.16 \pm 0.27^{\mathrm{ab}}$ & $12.87 \pm 0.59^{\mathrm{d}}$ & $10.34 \pm 0.99^{\mathrm{bcd}}$ & $7.23 \pm 0.09^{\mathrm{a}}$ \\
\hline & 180 & $6.26 \pm 0.42^{\mathrm{b}}$ & $3.65 \pm 0.08^{\mathrm{a}}$ & $3.24 \pm 0.35^{\mathrm{a}}$ & $3.32 \pm 0.36^{\mathrm{a}}$ & $2.38 \pm 0.23^{\mathrm{a}}$ & $2.94 \pm 0.16^{\mathrm{a}}$ & $2.22 \pm 0.08^{\mathrm{a}}$ \\
\hline & 270 & $4.33 \pm 0.67^{\mathrm{b}}$ & $1.46 \pm 0.02^{\mathrm{a}}$ & $1.06 \pm 0.03^{\mathrm{a}}$ & $1.30 \pm 0.10^{\mathrm{a}}$ & $0.97 \pm 0.02^{\mathrm{a}}$ & $1.70 \pm 0.13^{\mathrm{a}}$ & $1.23 \pm 0.07^{\mathrm{a}}$ \\
\hline & 360 & $3.21 \pm 0.27^{\mathrm{c}}$ & $1.00 \pm 0.19^{\mathrm{ab}}$ & $1.02 \pm 0.03^{\mathrm{ab}}$ & $1.71 \pm 0.13^{\mathrm{b}}$ & $0.91 \pm 0.09^{\mathrm{ab}}$ & $1.66 \pm 0.05^{\mathrm{ab}}$ & $0.75 \pm 0.06^{\mathrm{a}}$ \\
\hline
\end{tabular}

${ }^{\mathrm{a} e} \mathrm{e}$ Means in the same row followed by different superscripts differ $(P<0.05)$.

${ }^{1}$ Treatments were pressurized at $400 \mathrm{MPa}$ after $3 \mathrm{wk}$ of ripening (400W3), $600 \mathrm{MPa}$ after $3 \mathrm{wk}(600 \mathrm{~W} 3), 400 \mathrm{MPa}$ after 6 wk (400W6), $600 \mathrm{MPa}$ after 6 wk (600W6), 400 MPa after $9 \mathrm{wk}(400 \mathrm{~W} 9)$, and $600 \mathrm{MPa}$ after $9 \mathrm{wk}(600 \mathrm{~W} 9)$.

${ }^{2}$ Mean $\pm \mathrm{SE}(\mathrm{n}=4)$ of duplicate determinations in 2 cheese-making experiments. Activity is expressed in nanomole $p$-nitroaniline per minute per gram. 
Table 7. Overall proteolysis and free AA in control ovine milk blue cheese and pressurized cheeses

\begin{tabular}{|c|c|c|c|c|c|c|c|c|}
\hline Item & Days & Control cheese & $400 \mathrm{~W} 3^{1}$ & $600 \mathrm{~W} 3^{1}$ & $400 \mathrm{~W} 6^{1}$ & $600 \mathrm{~W} 6^{1}$ & $400 \mathrm{~W} 9^{1}$ & $600 \mathrm{~W} 9^{1}$ \\
\hline \multirow[t]{4}{*}{ Overall proteolysis $^{2}$} & 90 & $6.89 \pm 0.17^{\mathrm{bc}}$ & $5.25 \pm 0.62^{\mathrm{ab}}$ & $4.03 \pm 0.37^{\mathrm{a}}$ & $6.83 \pm 0.04^{\mathrm{bc}}$ & $5.23 \pm 0.05^{\mathrm{ab}}$ & $7.06 \pm 0.08^{c}$ & $6.55 \pm 0.83^{\mathrm{bc}}$ \\
\hline & 180 & $8.28 \pm 0.54^{\mathrm{d}}$ & $6.51 \pm 0.04^{\mathrm{b}}$ & $4.49 \pm 0.12^{\mathrm{a}}$ & $8.62 \pm 0.87^{\mathrm{d}}$ & $7.32 \pm 0.09^{c}$ & $8.85 \pm 0.40^{\mathrm{d}}$ & $7.00 \pm 0.32^{\mathrm{bc}}$ \\
\hline & 270 & $8.65 \pm 0.37^{\mathrm{c}}$ & $6.88 \pm 0.24^{\mathrm{b}}$ & $4.81 \pm 0.45^{\mathrm{a}}$ & $8.83 \pm 0.25^{\mathrm{c}}$ & $7.85 \pm 0.21^{\mathrm{bc}}$ & $9.01 \pm 0.12^{\mathrm{c}}$ & $8.52 \pm 0.37^{\mathrm{c}}$ \\
\hline & 360 & $10.42 \pm 0.29^{\mathrm{c}}$ & $8.10 \pm 0.14^{\mathrm{b}}$ & $5.53 \pm 0.42^{\mathrm{a}}$ & $11.38 \pm 0.51^{\mathrm{c}}$ & $8.78 \pm 0.16^{\mathrm{b}}$ & $10.40 \pm 0.17^{\mathrm{c}}$ & $8.96 \pm 0.63^{\mathrm{b}}$ \\
\hline \multirow[t]{4}{*}{ Total free $\mathrm{AA}^{2}$} & 90 & $61.20 \pm 3.67^{\mathrm{c}}$ & $42.09 \pm 2.89^{\mathrm{b}}$ & $25.21 \pm 1.31^{\mathrm{a}}$ & $64.68 \pm 6.64^{\mathrm{c}}$ & $59.64 \pm 2.51^{\mathrm{c}}$ & $63.04 \pm 3.70^{\mathrm{c}}$ & $59.66 \pm 2.91^{\mathrm{c}}$ \\
\hline & 180 & $88.61 \pm 2.10^{\mathrm{c}}$ & $60.10 \pm 3.28^{\mathrm{b}}$ & $36.46 \pm 0.72^{\mathrm{a}}$ & $90.96 \pm 1.08^{\mathrm{cd}}$ & $80.98 \pm 0.55^{\mathrm{c}}$ & $92.91 \pm 1.58^{\mathrm{d}}$ & $78.97 \pm 5.74^{\mathrm{c}}$ \\
\hline & 270 & $101.13 \pm 3.89^{\mathrm{cd}}$ & $73.55 \pm 5.61^{\mathrm{b}}$ & $38.77 \pm 2.62^{\mathrm{a}}$ & $108.28 \pm 0.24^{\mathrm{d}}$ & $84.73 \pm 1.35^{\mathrm{b}}$ & $101.86 \pm 3.83^{\mathrm{cd}}$ & $88.27 \pm 10.03^{\mathrm{bc}}$ \\
\hline & 360 & $116.76 \pm 1.42^{\mathrm{d}}$ & $81.45 \pm 3.46^{\mathrm{b}}$ & $54.33 \pm 5.70^{\mathrm{a}}$ & $116.68 \pm 0.77^{\mathrm{d}}$ & $95.80 \pm 1.42^{\mathrm{c}}$ & $123.48 \pm 1.08^{\mathrm{d}}$ & $94.81 \pm 1.15^{\mathrm{c}}$ \\
\hline
\end{tabular}

${ }^{\mathrm{a}-\mathrm{d}}$ Means in the same row followed by different superscripts differ $(P<0.05)$.

${ }^{1}$ Treatments were pressurized at $400 \mathrm{MPa}$ after 3 wk of ripening (400W3), $600 \mathrm{MPa}$ after 3 wk (600W3), $400 \mathrm{MPa}$ after 6 wk (400W6), $600 \mathrm{MPa}$ after 6 wk (600W6), $400 \mathrm{MPa}$ after 9 wk (400W9), and $600 \mathrm{MPa}$ after 9 wk (600W9).

${ }^{2}$ Mean $\pm \mathrm{SE}(\mathrm{n}=4)$ of duplicate determinations in 2 cheese-making experiments. Overall proteolysis estimated by the $o$-phthaldialdehyde method is expressed as the absorbance

at $340 \mathrm{~nm}$. Total free AA are expressed in milligrams per gram cheese DM.

Table 8. Main biogenic amines in control ovine milk blue cheese and pressurized cheeses

\begin{tabular}{|c|c|c|c|c|c|c|c|c|}
\hline Biogenic amine & Days & Control cheese & $400 \mathrm{~W} 3^{1}$ & $600 \mathrm{~W} 3^{1}$ & $400 \mathrm{~W} 6^{1}$ & $600 \mathrm{~W} 6^{1}$ & $400 \mathrm{~W} 9^{1}$ & $600 \mathrm{~W} 9^{1}$ \\
\hline \multirow[t]{3}{*}{ Tyramine $^{2}$} & 180 & $7.15 \pm 2.66^{\mathrm{ab}}$ & $7.80 \pm 1.09^{\mathrm{b}}$ & $6.57 \pm 1.70^{\mathrm{ab}}$ & $4.91 \pm 0.66^{\mathrm{a}}$ & $5.78 \pm 1.36^{\mathrm{a}}$ & $6.24 \pm 0.99^{\mathrm{ab}}$ & $4.62 \pm 1.21^{\mathrm{a}}$ \\
\hline & 270 & $26.70 \pm 2.92^{\mathrm{a}}$ & $25.78 \pm 6.30^{\mathrm{a}}$ & $24.78 \pm 5.85^{\mathrm{a}}$ & $18.63 \pm 2.83^{\mathrm{a}}$ & $24.46 \pm 3.84^{\mathrm{a}}$ & $23.15 \pm 2.45^{\mathrm{a}}$ & $23.84 \pm 3.37^{\mathrm{a}}$ \\
\hline & 360 & $52.20 \pm 9.56^{\mathrm{c}}$ & $32.01 \pm 2.55^{\mathrm{b}}$ & $33.43 \pm 2.43^{\mathrm{b}}$ & $20.90 \pm 1.68^{\mathrm{a}}$ & $32.39 \pm 1.92^{\mathrm{b}}$ & $30.62 \pm 5.86^{\mathrm{b}}$ & $27.22 \pm 1.79^{\mathrm{ab}}$ \\
\hline \multirow[t]{3}{*}{ Tryptamine $^{2}$} & 180 & $61.88 \pm 7.30^{\mathrm{ab}}$ & $67.07 \pm 9.71^{\mathrm{b}}$ & $46.33 \pm 5.06^{\mathrm{a}}$ & $54.29 \pm 6.01^{\mathrm{ab}}$ & $42.85 \pm 5.63^{\mathrm{a}}$ & $69.40 \pm 6.72^{\mathrm{b}}$ & $57.91 \pm 8.02^{\mathrm{ab}}$ \\
\hline & 270 & $70.59 \pm 5.17^{\mathrm{ab}}$ & $86.28 \pm 2.85^{\mathrm{b}}$ & $65.49 \pm 12.44^{\mathrm{a}}$ & $70.89 \pm 3.72^{\mathrm{ab}}$ & $73.59 \pm 2.61^{\mathrm{ab}}$ & $81.57 \pm 3.68^{\mathrm{ab}}$ & $74.76 \pm 5.10^{\mathrm{ab}}$ \\
\hline & 360 & $71.11 \pm 3.82^{\mathrm{a}}$ & $102.90 \pm 7.91^{\mathrm{bc}}$ & $76.77 \pm 4.93^{\mathrm{a}}$ & $74.69 \pm 4.32^{\mathrm{a}}$ & $104.40 \pm 3.10^{\mathrm{bc}}$ & $93.95 \pm 2.61^{\mathrm{ab}}$ & $120.09 \pm 3.94^{\mathrm{c}}$ \\
\hline \multirow[t]{3}{*}{ Phenylethylamine $^{2}$} & 180 & $13.25 \pm 0.94^{\mathrm{c}}$ & $8.13 \pm 2.53^{\mathrm{ab}}$ & $11.77 \pm 3.38^{\mathrm{bc}}$ & $5.07 \pm 0.80^{\mathrm{a}}$ & $8.18 \pm 0.43^{\mathrm{ab}}$ & $4.11 \pm 0.56^{\mathrm{a}}$ & $7.21 \pm 2.07^{\mathrm{a}}$ \\
\hline & 270 & $57.04 \pm 6.51^{\mathrm{a}}$ & $64.49 \pm 2.55^{\mathrm{ab}}$ & $61.05 \pm 5.55^{\mathrm{ab}}$ & $66.31 \pm 1.60^{\mathrm{ab}}$ & $54.50 \pm 4.15^{\mathrm{a}}$ & $80.68 \pm 9.81^{\mathrm{b}}$ & $75.31 \pm 9.22^{\mathrm{b}}$ \\
\hline & 360 & $61.44 \pm 2.79^{\mathrm{a}}$ & $74.22 \pm 5.47^{\mathrm{b}}$ & $77.71 \pm 9.95^{\mathrm{bc}}$ & $57.49 \pm 4.49^{\mathrm{a}}$ & $63.11 \pm 5.58^{\mathrm{ab}}$ & $70.70 \pm 6.19^{\mathrm{ab}}$ & $92.05 \pm 5.31^{\mathrm{c}}$ \\
\hline \multirow[t]{3}{*}{ Putrescine $^{2}$} & 180 & $17.28 \pm 1.33^{\mathrm{bc}}$ & $14.51 \pm 1.68^{\mathrm{a}}$ & $15.90 \pm 2.01^{\mathrm{ab}}$ & $12.67 \pm 0.87^{\mathrm{a}}$ & $19.52 \pm 3.15^{\mathrm{c}}$ & $13.03 \pm 1.40^{\mathrm{a}}$ & $18.70 \pm 2.46^{\mathrm{bc}}$ \\
\hline & 270 & $33.46 \pm 2.09^{\mathrm{a}}$ & $33.96 \pm 2.85^{\mathrm{a}}$ & $36.27 \pm 2.58^{\mathrm{a}}$ & $33.22 \pm 1.30^{\mathrm{a}}$ & $46.79 \pm 3.96^{\mathrm{b}}$ & $38.34 \pm 1.45^{\mathrm{a}}$ & $42.79 \pm 2.81^{\mathrm{ab}}$ \\
\hline & 360 & $32.97 \pm 2.05^{\mathrm{ab}}$ & $34.48 \pm 3.11^{\mathrm{ab}}$ & $39.50 \pm 3.55^{\mathrm{bc}}$ & $30.38 \pm 0.54^{\mathrm{a}}$ & $44.05 \pm 2.81^{\mathrm{cd}}$ & $31.00 \pm 2.81^{\mathrm{a}}$ & $49.70 \pm 2.79^{\mathrm{d}}$ \\
\hline
\end{tabular}

1 Treatments were pressured at $400 \mathrm{MPa}$ after 3 wh of ripening $(400 \mathrm{~W}), 600$

\& after $9 \mathrm{wk}(400 \mathrm{~W} 9)$, and $600 \mathrm{MPa}$ after $9 \mathrm{wk}(600 \mathrm{~W} 9)$.

Z $\quad{ }^{2}$ Mean $\pm \mathrm{SE}(\mathrm{n}=4)$ of duplicate determinations in 2 cheese-making experiments. Biogenic amines are expressed in milligrams per kilogram of cheese DM. 
cheeses. Spermidine was found on d 270 and 360 at low concentrations, ranging from 5.06 to $14.03 \mathrm{mg} / \mathrm{kg}$ of $\mathrm{DM}$, in control cheese and in some of the HP-treated cheeses (data not shown). Spermine and spermidine may be formed by starter LAB. These polyamines were detected at low levels, $0.20 \mathrm{mg} / \mathrm{L}$ of spermine and $0.75 \mathrm{mg} / \mathrm{L}$ of spermidine, in sterilized nonfat milk, and increased during the fermentation of milk with added rennet by Lactococcus lactis to levels as high as 1.7 and $10 \mathrm{mg} / \mathrm{L}$, respectively (Santos et al., 2003). According to those authors, spermine reached a maximum after 12 $\mathrm{h}$ at $20^{\circ} \mathrm{C}$ and had practically disappeared $12 \mathrm{~h}$ later. Concentrations of spermidine and spermine in the present study are in agreement with those found for pressurized and control goat milk cheeses, which contained higher concentrations of spermidine, ranging from 14.7 to $26.4 \mathrm{mg} / \mathrm{kg}$ of $\mathrm{DM}$, than of spermine, which ranged from 0.9 to $3.5 \mathrm{mg} / \mathrm{kg}$ of DM (Novella-Rodríguez et al., 2002).

Tyramine, which was not detected on d 90 in any of the cheeses, attained significantly $(P<0.05)$ lower levels on d 360 in all the pressurized cheeses than in control cheese (Table 8). The low tyramine concentrations found in the present work and the absence of histamine can be related to the low counts of enterococci and lactobacilli, potential tyrosine and histidine decarboxylase-positive bacteria, but also to the low cheese-ripening and storage temperatures used, $5{ }^{\circ} \mathrm{C}$ from d 30 to 90 , and $3^{\circ} \mathrm{C}$ from d 90 onwards, which impair BA formation (Stratton et al., 1991). Tyrosine and histidine concentrations in cheeses on d 360, which ranged from 4.11 to 9.29 and from 3.80 to $9.86 \mathrm{mg} / \mathrm{g}$ of DM (data not shown), respectively, did not appear as limiting factors for tyramine and histamine formation. Tryptamine, which was below detection level in all cheeses on d 90, reached higher concentrations in 400W3, 600W6, and 600W9 cheeses by d 360 than in control cheese. Phenylethylamine was found in all cheeses on d 90 at low concentrations, ranging from 4.96 to $13.28 \mathrm{mg} / \mathrm{kg}$ of DM (data not shown), and attained higher levels in 400W3,600W3, and 600W9 by d 360 cheeses than in control cheese (Table 8). Putrescine was also detected in all cheeses at low concentrations on d 90, ranging from 5.38 to $8.65 \mathrm{mg} / \mathrm{kg}$ of DM (data not shown), and reached higher concentrations in 600W6 and 600W9 cheeses by d 360 than in control cheese (Table 8). During the fermentation of sterilized nonfat milk with added rennet by L. lactis, up to 0.82 $\mathrm{mg} / \mathrm{L}$ of tyramine and $0.15 \mathrm{mg} / \mathrm{L}$ of putrescine were formed, but phenylethylamine and tryptamine were not detected (Santos et al., 2003). In the present work, the concentrations of phenylalanine, tryptophan, and arginine in control and pressurized cheeses did not seem to limit the formation of the respective biogenic amines, similarly to tyrosine and histidine.

Biogenic amines formation through free AA decarboxylation may constitute an alternative energy source for cheese microbiota in the absence of fermentable carbohydrates (Fernandez-García et al., 2000). Conversely, some strains of Lactobacillus, Pediococcus, and Micrococcus are capable of degrading BA, such as tyramine and histamine, by means of monoamine oxidases, preferably under aerobic conditions (Leuschner et al., 1998). Accumulation of BA is thus the result of BA formation and degradation by cheese microbiota.

Concentrations of BA reported for blue-veined cheeses show a considerable variability, and do not seem to be related to the use of raw or pasteurized milk. Roquefort cheese contained, on average, 19, 40, 65, and $158 \mathrm{mg} /$ $\mathrm{kg}$ of histamine, tyramine, putrescine, and cadaverine, respectively (De Vuyst et al., 1976), and Stilton cheese contained 39, 121, 11, and $126 \mathrm{mg} / \mathrm{kg}$ of histamine, tyramine, phenyletylamine, and putrescine, respectively (Baker et al., 1987). Roquefort cheese has been always made from raw milk, and Stilton cheese was made from unpasteurized milk at the time of the cited work (Gkatzionis et al., 2009). High concentrations of BA, $490 \mathrm{mg} / \mathrm{kg}$ of histamine and $625 \mathrm{mg} / \mathrm{kg}$ of tyramine, were found for Danish blue cheese (Ingles et al., 1985) and for Spanish blue cheese made from raw milk, which contained $1,042 \mathrm{mg} / \mathrm{kg}$ of histamine and $1,052 \mathrm{mg} / \mathrm{kg}$ of tyramine (Fernández et al., 2007). For Egyptian raw milk blue cheese, up to $36,2,220,27,12$, and $16 \mathrm{mg} / \mathrm{kg}$ of DM of histamine, tyramine, putrescine, and cadaverine, respectively, were found (Rabie et al., 2011). Those authors achieved significant decreases in histamine and tyramine contents by cheese irradiation at $4 \mathrm{kGy}$, and in putrescine and cadaverine contents by irradiation at $6 \mathrm{kGy}$.

\section{Sensory Characteristics}

Flavor intensity scores of pressurized cheeses did not differ from those of control cheese, with the only exception of $600 \mathrm{~W} 3$ cheese scores, which were significantly $(P<0.05)$ lower than those of control cheese (Table 9$)$. The scores obtained for flavor quality were also generally lower for $600 \mathrm{~W} 3$ cheeses than for the rest (Table 9). The low flavor scores of $600 \mathrm{~W} 3$ cheese can be associated to its higher levels of hydrophobic peptides and peptide ratio, and its lower levels of overall proteolysis and total free AA. In fact, significant $(P<0.05) \mathrm{r}^{2}$ values of 0.758 and 0.808 were obtained for the regressions of flavor intensity scores on free AA contents in all cheeses on $\mathrm{d} 270$ and 360 , respectively, and $\mathrm{r}^{2}$ values of 0.830 and 0.934 for the regressions of flavor quality scores on 
free AA contents on d 270 and 360. Cheese treatment at a high pressure level $(600 \mathrm{MPa})$ at an early ripening stage (3 wk) negatively affected biochemical changes and sensory characteristics. The flavor attributes acid, bitter, salty, sweet, and umami attained similar scores in control and pressurized cheeses and, with the exception of umami scores, which increased significantly $(P$ $<0.05)$ with time, did not vary during the refrigerated storage period (data not shown).

No sensory evaluation was carried out on Irish blueveined cheese (Voigt et al., 2010). In the case of Gorgonzola blue cheese, treatments at 600 and $700 \mathrm{MPa}$ did not reduce the acceptance by untrained panelists, and no changes in the bitter, salty, and piquant attributes were observed (Carminati et al., 2004). Conversely, a negative effect of irradiation on the odor and taste of Egyptian raw milk blue cheese was recorded when this procedure was assayed to reduce the formation of BA (Rabie et al., 2011).

\section{CONCLUSIONS}

Pressurization of blue-veined cheese lowered microbial counts, in particular treatments at $600 \mathrm{MPa}$, which reduced LAB counts by more than $4 \log$ units and $P$. roqueforti counts by more than $6 \log$ units. The levels of residual caseins were generally higher in $600 \mathrm{MPa}$ cheeses than in the rest of the cheeses. Hydrophilic peptides reached similar levels in pressurized and control cheeses from d 90 onwards, but the level of hydrophobic peptides tended to be higher in pressurized cheeses. Aminopeptidase activity, overall proteolysis, and free AA contents were generally higher in control cheese than in pressurized cheeses. Tyramine concentration was lower in pressurized cheeses than in control cheese, but higher tryptamine, phenylethylamine, and putrescine contents were found in some of the pressurized cheeses, in particular in cheese pressurized at $600 \mathrm{MPa}$ after 9 wk of ripening, than in control cheese. Differences in sensory characteristics between pressurized and control cheeses were generally negligible, with the exception of treatment at a high pressure level $(600 \mathrm{MPa})$ at an early ripening stage (3 wk), which negatively affected biochemical changes and sensory characteristics.

\section{ACKNOWLEDGMENTS}

This work was supported by project AGL2009-07801 from the Ministry of Science and Innovation (MICINN; Madrid, Spain). J. Calzada was the recipient of a MICINN fellowship. The authors are grateful for the valuable help of V. Carbonero (Lácteas Toledo, Guadamur, Spain) with cheese supply and of F. Purroy (NC Hyperbaric, Burgos, Spain) with high pressure treatments. 


\section{REFERENCES}

Arqués, J. L., S. Garde, E. Fernández-García, P. Gaya, and M. Nuñez. 2007. Volatile compounds, odor, and aroma of La Serena cheese high-pressure treated at two different stages of ripening. J. Dairy Sci. 90:3627-3639.

Arqués, J. L., S. Garde, P. Gaya, M. Medina, and M. Nuñez. 2006. Inactivation of microbial contaminants in raw milk La Serena cheese by high pressure treatments. J. Dairy Sci. 89:888-891.

Baker, G. B., J. T. F. Wong, R. T. Coutts, and F. M. Pasutto. 1987. Simultaneous extraction and quantitation of several bioactive amines in cheese and chocolate. J. Chromatogr. 392:317-331.

Carminati, D., M. Gatti, B. Bonvini, E. Neviani, and G. Mucchetti 2004. High-pressure processing of Gorgonzola cheese: Influence on Listeria monocytogenes inactivation and on sensory characteristics. J. Food Prot. 67:1671-1675.

Church, F. C., H. E. Swaisgood, D. H. Porter, and G. L. Catignani. 1983. Spectrophotometric assay using o-phtaldialdehyde for determination of proteolysis in milk and isolated milk proteins. J. Dairy Sci. 66:1219-1227.

De Vuyst, A., W. Vervack, and M. Foulon. 1976. Détection d'amines non volatiles dans quelques fromages. Lait 56:414-422.

Delgado, F. J., J. Gonzalez-Crespo, R. Cava, and R. Ramirez. 2012. Changes in microbiology, proteolysis, texture and sensory characteristics of raw goat milk cheeses treated by high-pressure at different stages of maturation. LWT-Food Sci. Technol. 48:268-275.

Edwards, S. T., and W. E. Sandine. 1981. Public health significance of amines in cheese. J. Dairy Sci. 64:2431-2438.

Evert-Arriagada, K., M. M. Hernández-Herrero, B. Juan, B. Guamis, and A. J. Trujillo. 2012. Effect of high-pressure on fresh cheese shelf-life. J. Food Eng. 110:248-253.

Fernández, M., D. M. Linares, B. del Río, V. Ladero, and M. A. Alvarez. 2007. HPLC quantification of biogenic amines in cheeses: Correlation with PCR-detection of tyramine-producing microorganisms. J. Dairy Res. 74:276-282.

Fernandez-García, E., J. Tomillo, and M. Nuñez. 2000. Formation of biogenic amines in raw milk Hispánico cheese manufactured with proteinases and different levels of starter culture. J. Food Prot. 63:1551-1555.

Garde, S., J. L. Arqués, P. Gaya, M. Medina, and M. Nuñez. 2007. Effect of high pressure treatments on the proteolysis and texture of ewes' raw milk La Serena cheese. Int. Dairy J. 17:1424-1433.

Garde, S., M. Ávila, P. Gaya, M. Medina, and M. Nuñez. 2006. Proteolysis of Hispánico cheese manufactured using lacticin 481-producing Lactococcus lactis ssp. lactis INIA 639. J. Dairy Sci. 89:840849 .

Garde, S., J. Tomillo, P. Gaya, M. Medina, and M. Nuñez. 2002. Proteolysis in Hispánico cheese manufactured using a mesophilic starter, a thermophilic starter and bacteriocin-producing Lactococcus lactis ssp. lactis INIA 415 adjunct culture. J. Agric. Food Chem. 50:3479-3485.

Gkatzionis, K., R. S. T. Linforth, and C. E. R. Dodd. 2009. Volatile profile of Stilton cheeses: Differences between zones within a cheese and dairies. Food Chem. 113:506-512.

Gobbetti, M., R. Burzigotti, E. Smacchi, A. Corsetti, and M. De Angelis. 1997. Microbiology and biochemistry of Gorgonzola cheese during ripening. Int. Dairy J. 7:519-529.

Gomez, M. J., S. Garde, P. Gaya, M. Nuñez, and M. Medina. 1997. Relationship between level of hydrophobic peptides and bitterness in cheese made from pasteurized and raw milk. J. Dairy Res. 64:289-297.

Gomez, M. J., E. Rodríguez, P. Gaya, M. Nuñez, and M. Medina. 1999. Characteristics of Manchego cheese manufactured from raw and pasteurized ovine milk and with defined-strain and or commercial mixed-strain starter cultures. J. Dairy Sci. 82:2300-2307.

Gripon, J.-C., M. J. Desmazeaud, D. Le Bars, and J. L. Bergère. 1977. Role of proteolytic enzymes of Streptococcus lactis, Penicillium roqueforti, and Penicillium caseicolum during cheese ripening. J. Dairy Sci. 60:1532-1538.
Ingles, D. L., J. F. Black, D. Gallimore, R. Tindale, and K. J. Shaw. 1985. Estimation of biogenic-amines in foods. J. Sci. Food Agric. $36: 402-406$.

Joosten, H. M. L. J., and M. D. Northolt. 1987. Conditions allowing the formation of biogenic-amines in cheese. 2. Decarboxylase properties of some nonstarter bacteria. Neth. Milk Dairy J. $41: 259-280$.

Juan, B., V. Ferragut, M. Buffa, B. Guamis, and A. J. Trujillo. 2007. Effects of high pressure on proteolytic enzymes in cheese: Relationship with the proteolysis of ewe milk cheese. J. Dairy Sci. 90:2113-2125.

Krause, I., A. Bockhardt, H. Neckermann, T. Henle, and H. Klostermeyer. 1995. Simultaneous determination of amino acids and biogenic amines by reversed-phase high-performance liquid chromatography of the dabsyl derivatives. J. Chromatogr. A 715:67-79.

Lau, K. Y., D. M. Barbano, and R. R. Rasmussen. 1991. Influence of pasteurization of milk on protein breakdown in Cheddar cheese during aging. J. Dairy Sci. 74:727-740.

Leuschner, R. G., M. Heidel, and W. P. Hammes. 1998. Histamine and tyramine degradation by food fermenting microorganisms. Int. J. Food Microbiol. 39:1-10.

Madkor, S., P. F. Fox, S. I. Shalabi, and N. H. Metwalli. 1987. Studies on the ripening of Stilton cheese: Proteolysis. Food Chem. 25:13-29.

Malone, A. S., C. Wick, T. H. Shellhammer, and P. D. Courtney. 2003. High pressure effects on proteolytic and glycolytic enzymes involved in cheese manufacturing. J. Dairy Sci. 86:1139-1146.

Modler, H. W., J. R. Brunner, and C. M. Stine. 1974. Extracellular protease of Penicillium roqueforti. I. Production and characteristics of crude enzyme preparation. J. Dairy Sci. 57:523-527.

Novella-Rodríguez, S., M. T. Veciana-Nogués, J. Saldo, and M. C Vidal-Carou. 2002. Effects of high hydrostatic pressure treatments on biogenic amine contents in goat cheeses during ripening. J. Agric. Food Chem. 50:7288-7292.

O'Reilly, C. E., A. L. Kelly, J. C. Oliveira, P. M. Murphy, M. A. E. Auty, and T. P. Beresford. 2003. Effect of varying high-pressure treatment conditions on acceleration of ripening of Cheddar cheese. Innov. Food Sci. Emerg. Technol. 4:277-284.

O'Reilly, C. E., P. M. O'Connor, A. L. Kelly, T. P. Beresford, and P. M. Murphy. 2000. Use of hydrostatic pressure for inactivation of microbial contaminants in cheese. Appl. Environ. Microbiol. 66:4890-4896.

Pircher, A., F. Bauer, and P. Paulsen. 2007. Formation of cadaverine, histamine, putrescine and tyramine by bacteria isolated from meat, fermented sausages and cheeses. Eur. Food Res. Technol. 226:225-231.

Rabie, M. A., H. I. Siliha, S. M. El-Saidy, A. A. El-Badawy, and F. X. Malcata. 2011. Effect of $\gamma$-irradiation upon biogenic amine formation in blue cheese during storage. Int. Dairy J. 21:373-376.

Saldo, J., P. L. H. McSweeney, E. Sendra, A. L. Kelly, and B. Guamis. 2002. Proteolysis in caprine milk cheese treated by high pressure to accelerate cheese ripening. Int. Dairy J. 12:35-44.

Santos, W. C., M. R. Souza, M. M. O. P. Cerqueira, and M. B. A. Gloria. 2003. Bioactive amines formation in milk by Lactococcus in the presence or not of rennet and $\mathrm{NaCl}$ at 20 and $32{ }^{\circ} \mathrm{C}$. Food Chem. 90:219-230.

Silla Santos, M. H. 1996. Biogenic amines: Their importance in foods. Int. J. Food Microbiol. 29:213-231.

Stratton, J. E., R. W. Hutkins, and S. L. Taylor. 1991. Biogenic amines in cheese and other fermented foods. J. Food Prot. 54:460-470.

Taylor, S. L. 1986. Histamine food poisoning: Toxicology and clinical aspects. Crit. Rev. Toxicol. 17:91-128.

ten Brink, B.. C. Damink, H. M. L. J. Joosten, and J. H. Huis in 't Veld. 1990. Occurrence and formation of biologically-active amines in foods. Int. J. Food Microbiol. 11:73-84.

Til, H. P., H. E. Falke, M. K. Prinsen, and M. I. Willems. 1997. Acute and subacute toxicity of tyramine, spermidine, spermine, putrescine and cadaverine in rats. Food Chem. Toxicol. 35:337-348. 
Trieu-Cuot, P., M.-J. Archieri-Haze, and J.-C. Gripon. 1982. Effect of aspartyl proteinases of Penicillium caseicolum and Penicillium roqueforti on caseins. J. Dairy Res. 49:487-500.

Visser, S. 1993. Proteolytic enzymes and their relation to cheese ripening and flavor: An overview. J. Dairy Sci. 76:329-350.

Voigt, D. D., F. Chevalier, M. C. Qian, and A. L. Kelly. 2010. Effect of high-pressure treatment on microbiology, proteolysis, lipolysis and levels of flavor compounds in mature blue-veined cheese. Innov. Food Sci. Emerg. Technol. 11:68-77.
Wick, C., U. Nienaber, O. Anggraeni, T. H. Shellhammer, and P. D. Courtney. 2004. Texture, proteolysis and viable lactic acid bacteria in commercial Cheddar cheeses treated with high pressure. J. Dairy Res. 71:107-115.

Yvon, M., and L. Rijnen. 2001. Cheese flavor formation by amino acid catabolism. Int. Dairy J. 11:185-201. 